\title{
Palaeoenvironmental reconstructions during the Meso- to Neolithic transition (9.2-5.3 cal. ka BP) in Northwestern France: Palynological evidences
}

\author{
Lambert Clément ${ }^{1,{ }^{*}}$, Vidal Muriel ${ }^{1}$, Penaud Aurélie ${ }^{1}$, Le Roy Pascal ${ }^{1}$, Goubert Evelyne ${ }^{2}$, \\ Pailler Yvan ${ }^{3}$, Stephan Pierre ${ }^{4}$, Ehrhold Axel ${ }^{5}$
}

${ }^{1}$ Laboratoire Géosciences Océan (UMR 6538), IUEM, CNRS, Université de Bretagne Occidentale (UBO), France

${ }^{2}$ Laboratoire Géosciences Océan (UMR 6538), IUEM, CNRS, Université de Bretagne Occidentale

(UBO), Université Bretagne Sud, France

${ }^{3}$ Grand-Ouest, INRAP, France

${ }^{4}$ LETG Brest GEOMER, IUEM, UMR 6554, CNRS, Université de Bretagne Occidentale (UBO), France

${ }^{5}$ Géosciences Marines, Centre de Brest, IFREMER, France

* Corresponding author : Clément Lambert, email address : clement.lambert24@gmail.com

\begin{abstract}
:
Sedimentological, palynological, and micropalaeontological studies carried out throughout the first half of the Holocene, during the Mesolithic/Neolithic transition in the Bay of Brest (i.e. 9200-9000 and 66005300 cal. BP) and in the Bay of Douarnenez (i.e. 9200-8400 cal. BP), allowed characterizing coastal environmental changes under the increasing influence of the relative sea-level rise. The gradual flooding of the two studied sites implied a transition from river valleys to oceanic bays as revealed by the gradual retreat of salt marsh environments, as detected through palynological analysis. In addition, these high-resolution studies highlight the regional imprint of the North Atlantic millennial climate variability in north-western coastal environments. Two cold climate events are indeed suggested to have been locally marked by a moisture increase, mainly detected by increases in Lingulodinium machaerophorum, Corylus, and Alnus percentages at $8550 \mathrm{cal}$. BP in the Bay of Douarnenez and at $6250 \mathrm{cal}$. BP in the Bay of Brest. Moreover, regarding the Neolithic transition timing in the Bay of Douarnenez, large pollen grains of Poaceae (i.e. Cerealia-type pollen grains) have been detected at around $8600 \mathrm{cal}$. BP, that is, 1500 years before the general accepted cereal cropping appearance in Western France. These results, consistent with other palynological studies conducted in the French Atlantic coast, could underline a Mesolithic 'proto-agriculture' in Brittany.
\end{abstract}

Keywords: benthic foraminifera, climate variability, dinoflagellate cysts, human impacts, palaeoenvironments reconstructions, pollen grains 


\section{Introduction}

The Holocene is characterized by a gradual decrease in summer air temperatures and seasonality (seasonal thermal amplitude) in line with the continuing summer insolation decrease at $65^{\circ} \mathrm{N}$ (Berger and Loutre, 1991). Sub-millennial climate variability is superimposed on this long-term climate trend, as shown by numerous studies carried out on marine (e.g. Bond et al., 1997, 2001; Mayewski et al., 2004), terrestrial (e.g. Davis et al., 2003) and glacial records (e.g. O'Brien et al., 1995), highlighting iterated abrupt climate events also referred as "Bond events" (Bond et al., 1997, 2001) or RCC (i.e. "Rapid Climate Change"; Mayewski et al., 2004). These events are often associated with significant climate cooling in North Atlantic surface waters and over northern Europe, as well as increasing aridity in the tropics (Mayewski et al., 2004; Hammarlund et al., 2005; Wanner et al., 2011). Finally, on decadal to multi-decadal timescales, climate over northern Europe is forced by the combined influences of atmospheric and oceanic natural oscillations, themselves driven by different teleconnections and physico-chemical exchanges at the air/ocean interface (Knight et al., 2006; Tréguer et al., 2014; McCarthy et al., 2015; Ruprich-Robert and Cassou, 2015).

The geographical exposure of the coast to the ocean and North Atlantic climate hazards thus makes the Northwest coast of France a favorite environment for the study of current and past climate. In addition to these factors, coastal areas are constantly changing shaped by different dynamic agents. The sea level-rise occurring across the deglaciation has also impacted coastal environments from a geomorphological, sedimentological and ecological point of view. On a regional scale, recent studies reconstructed and quantified the post-glacial sea-level rise on Brittany's coasts (Goslin et al., 2013, 2015; Stéphan et al., 2015; García-Artola et al., 2018), estimated from about 10 to $15 \mathrm{~mm} /$ year between the end of the last glacial period and 9,000 years cal BP to around $4.6 \mathrm{~mm} /$ year between 7,500 and 6,500 years cal BP, and less than 1 
$\mathrm{mm} /$ year after 6,000 years cal BP. Moreover, palaeoecological data recently acquired on Holocene Brittany's coastal sequences discussed past environmental variations (vegetation changes, palaeo-storm dynamics, precipitation regimes) and linked these rapid coastal changes with climate dynamics as well as human occupation on watersheds (Fernane et al., 2014, 2015). These studies especially focused on the Neolithic, a period when the development of agro-pastoral societies became more and more pronounced (Visset and Bernard, 2006; Pailler et al., 2011).

In this study, new sequences retrieved in two sites from the westernmost part of Brittany (NW France), the Bay of Brest (BB) and the Bay of Douarnenez (BD), cover the Mesolithic to Neolithic transition, a still fairly unknown period so far. They allow a multidisciplinary approach based on pollen, dinoflagellate cyst (dinocyst) and foraminiferal analyses, as well as on stable isotopes and sedimentological data. Pollen analysis provides information regarding surrounding vegetation changes on $\mathrm{BB}$ and $\mathrm{BD}$ watersheds through time. Indeed, palynological studies carried out on modern BB sediments (Lambert et al., 2017), as well as across the last 150 years (Lambert et al., 2018), evidenced the robustness of studying fossilized pollen grains in BB sediment archives to discuss both natural and anthropogenic forcings. These include: hydrodynamics, fluvial discharges, pollination rates, or agricultural watershed policy. Dinoflagellates are phytoplanktonic organisms that play an important role in the trophic network. Numerous studies carried out on modern marine sediments showed specific patterns regarding the spatial distribution of fossilizable dinocysts according to seasurface temperature and salinity, sea-ice cover duration, inshore-offshore gradient and/or nutrient concentration (Morzadec-Kerfourn, 1977, 1979; Dodge et Harland, 1991; Rochon et de Vernal, 1994; Mudie et al., 2001; Marret and Zonneveld, 2003; Zonneveld et al., 2013; de Vernal et al., 2013). These palynomorphs have been observed with extremely low concentrations and a poor species richness in modern BB sediments (Lambert et al., 2017) but 
have proved to be excellent markers for reconstructing past BB sea-surface conditions across the last century (Lambert et al., 2018). Finally, benthic foraminifera are particularly sensitive to various environmental factors (temperature, salinity, oxygenation, $\mathrm{pH}$, hydrodynamism, organic matter export, water depth) and are frequently used to reconstruct bottom watercolumn conditions (Gooday, 2003; Jorissen et al., 2007). In coastal environments, foraminiferal species allow reconstructing natural or human-induced environmental changes (Debenay et al., 2006; Delaine et al., 2015), and among the rare studies conducted in the BB with this proxy, Stéphan (2008) applied it to discuss palaeobathymetric evolution in saltmarsh environments related to the Holocene sea-level rise (Stéphan and Goslin, 2014 ; Stéphan et al., 2015; García-Artola et al., 2018).

In this paper, we thus aim at discussing the combined influences of local (i.e. watersheds) versus regional (i.e. northern European climate) factors driving paleoenvironmental changes across the first half of the Holocene in western Brittany (from 9,200 to 5,300 cal BP), thanks to a cross-correlated pollen-dinocyst-foraminiferal analysis and a pluri-decadal timescale resolution. Furthermore, the studied period covers the Mesolithic to the Neolithic transition, where the environmental changes thanks to the Neolithization must be detectable in paleoenvironmental sequences.

\section{Environmental contexts}

\subsection{Present and past sedimentological contexts of study sites}

The cores selected for this study are located in the westernmost part of Brittany, in marine coastal bays located on both sides of the Crozon peninsula (Fig. 1a). 
The BD is a large circular bay $\left(350 \mathrm{~km}^{2}\right)$ limited by the Crozon peninsula to the North and the Cap Sizun to the South, largely connected to the Iroise Sea by a passage of about $9 \mathrm{~km}$ wide (Fig. 1b). Its bathymetry reveals a concave morphology characterized by a water depth of about $20 \mathrm{~m}$, reaching $30 \mathrm{~m}$ in the center of the bay (Augris et al., 2005; Fig. 1b). The geological basement of the BD and its surroundings corresponds to Brioverian/Palaeozoic sandstones and schist in the North, and metamorphic/plutonic formations in the South (Mélou and Plusquellec, 1974; Augris et al., 2005). A major NW-SE trending fault network (Kerforne fault system) affects the BD, inherited from the Hercynian orogeny and reactivated during the North Atlantic opening (Lefort, 1973; Ballèvre et al., 2013). Coasts are mainly shaped by cliffs up to $100 \mathrm{~m}$ high in the Crozon peninsula and $85 \mathrm{~m}$ towards the Cap Sizun. Some valleys and small estuaries drain very restricted watersheds (40 $\mathrm{km}^{2}$ for the larger), sometimes open between cliffs, protecting wetlands and marshes behind the shoreline (Augris et al., 2005). The BD does not receive a large amount of freshwater, implying a strong marine influence with a maximum tidal amplitude of $8 \mathrm{~m}$ and a relatively stable salinity (around 35\%; Augris et al., 2005).

The BD sedimentary cover mainly consists of gravels and coarse sands in the central part of the bay and fine sands in sheltered areas (Hinschberger and Pauvret, 1968; Augris et al., 1988), reaching a thickness of $18 \mathrm{~m}$ in palaeo-valley axes, but remaining relatively thin over the whole BD (2 to $4 \mathrm{~m}$; Augris et al., 2005). The substratum study reveals a dendritic palaeochannel network incising Brioverian basement and flowing into a main valley in the center of the bay named the Ys palaeo-valley (Fig. 1b). These channels are connected to the main continental rivers surrounding the BD (Musset, 1934; Guilcher, 1948; Hallegouët, 1989; Jouet et al., 2003). The sedimentary infilling history of the BD is based on the analysis of seismic units (U1 to U6; Fig. 2) combined with analysis of numerous sediment cores (Jouet et 
al., 2003; Le Roy and Jouet, 2005). While the BD was totally emerged during the Last Glacial Maximum (around 20,000 years BP), its flooding, initially confined to palaeo-valleys (10,000-8,000 years BP, meander bar units U3 and U4; Fig. 2), then spread out to the rest of the BD (8,000-5,000 years BP, fine estuarine sedimentation U5; Fig. 2). The sea level was stabilized at about 6,000-5,000 years BP (Goslin et al., 2015) and, since then, reworked marine sands form the upper unit of the BD sediment cover (U6; Fig. 2).

\section{$\underline{\text { The Bay of Brest (BB) }}$}

The BB is located in north-western Brittany (NW France; Fig. 1c) and consists of a shallow semi-enclosed basin of $180 \mathrm{~km}^{2}$ surrounded by a $230 \mathrm{~km}$ long coastline. Its basement corresponds to Proterozoic igneous rocks in the north and Brioverian/Palaeozoic sediments in the south and east. Present-day low reliefs (few hills reach $330 \mathrm{~m}$ high) are inherited from the peneplanation of the Hercynian chain (Chauris and Plusquellec, 1980; Ballèvre et al., 2009). The study area has been subsiding since the Eocene and still today $(0.02$ to $0.04 \mathrm{~mm} / \mathrm{yr}$; Ziegler, 1992; Bonnet et al., 2000; Goslin, 2014), but it can be considered as negligible at the Holocene timescale $(40 \mathrm{~mm} / 10,000$ years ; Goslin et al., 2015). The river system is established since the Tertiary (Hallegouët et al., 1994). Today, the BB is characterized by a macrotidal influence with a maximum tidal amplitude of $8 \mathrm{~m}$ (Troadec and Le Goff, 1997). Grain size analyses of modern sediments reflect specific hydrodynamic conditions mainly related to tidal currents (Gregoire et al., 2016). In its westernmost part, the BB is connected to the Atlantic Ocean through the "Goulet" (Fig. 1c), a strait of about $1.8 \mathrm{~km}$ wide and $50 \mathrm{~m}$ deep. In its easternmost part, the $\mathrm{BB}$ receives main freshwater supplies from the Aulne and Elorn Rivers (both contributing up to $85 \%$ of the total river discharges; Delmas and Treguer, 1983), as well as from the smaller Daoulas River (Fig. 1c). BB watersheds are characterized by $2,000 \mathrm{~km}$ of waterways and most of their runoff flows into the BB through the Aulne River 
(114 km long; 1,224 km² of watershed and $20.40 \mathrm{~m}^{3} / \mathrm{s}$ of annual debit; Troadec and Le Goff, 1997).

The bathymetric map of the BB highlights submarine channels that attest to palaeo-fluvial systems (Fig. 1c; Gregoire et al., 2016). Palaeo-channels of the two main current rivers, Aulne and Elorn, are about 30 and $15 \mathrm{~m}$ deep respectively, and converge in the west at a trough of about $50 \mathrm{~m}$ deep (Troadec and Le Goff, 1997). Nevertheless, at present, the depth of the BB does not exceed $10 \mathrm{~m}$ deep on approximately $60 \%$ of its surface (Monbet and Bassoulet, 1989). The last transgressive episode corresponds to the complex and fragmented sedimentary infilling history of the BB (Gregoire et al., 2017), because of i) the nonmorphological uniformity of the substratum, ii) the non-linear post-glacial sea level rise, combined with iii) strong and complex hydrodynamical features (Gregoire et al., 2017). Palaeo-valleys became flooded according to different steps of large fluvial terraces (Gregoire et al., 2017), considerably decreasing surfaces occupied by intertidal salt-marshes and mudflats (i.e. typical environments submitted to intertidal dynamics); the shallowest parts of the BB being flooded between 9,000 and 7,000 years BP. Today, the centre of the BB is predominantly under marine influence, main river mouths and intertidal areas having migrated further east.

\subsection{Climatic Context}

Brittany is subjected to a temperate oceanic climate regime characterized by the influence of the westerlies and by low seasonal thermal amplitudes with mean annual temperatures of about $10-11^{\circ} \mathrm{C}$ (Belleguic et al., 2012). Annual prevailing winds (with speeds that can exceed $100 \mathrm{~km} / \mathrm{h}$ during 5 to 15 days per year) have mainly a south-west origin (Troadec and Le Goff, 1997). Since Brittany is submitted to regular oceanic rainfalls, annual cumulative precipitation 
data ranges from $600 \mathrm{~mm} /$ year to more than $1,600 \mathrm{~mm} /$ year in the inner continental part (Troadec and Le Goff, 1997; Belleguic et al., 2012). The climate of Brittany is due to the combined influences of atmospheric (North Atlantic Oscillation, NAO) and oceanic (Atlantic Multidecadal Oscillation, AMO) circulations detailed thereafter (Tréguer et al., 2014, Ruprich-Robert and Cassou, 2015; Lambert et al., 2018). On decadal to multi-decadal timescales, variations in North Atlantic sea-surface temperature (SST) control a large part of the climate variability reconstructed on the continent (Deser et al., 2010; Knight et al., 2006; McCarthy et al., 2015; Ruprich-Robert and Cassou, 2015), already discussed in the BB watersheds (Lambert et al., 2018).

\subsection{Cultural evolution and territorial occupation dynamics}

The Mesolithic is poorly documented in western Brittany due to the scarcity of archeological data. The French Mesolithic period is divided into two sub periods, the first Mesolithic (10th, 9th, and 8th millennia BC) and the second Mesolithic (7th, 6th and early 5th millennia BC, depending on the studied region) according to cultural criteria based on lithic industries (Marchand, 2014). Across the Mesolithic, traces of shellfish consumption as well as of microlithic industries on the coastline suggest the presence of small communities irregularly spread over western Brittany (perhaps 25,000 to 50,000 people; Giot et al., 1998). Also, lithic material resulting from debitage has been found in Finistère (western Brittany), evidencing human settlements 20 kilometers from the current coast. Human groups may have moved seasonally between coasts, riversides and the inner land (Gouletquer et al., 1994, 1996), while recent studies rather suggest perennial settlements of restricted communities in some coastal areas (Schulting and Richards, 2001; Marchand, 2005). Previous pollen studies have not shown significant environmental impacts in Brittany due to human hunter-gatherer populations (Morzadec-Kerfourn, 1974). 
The Neolithic "revolution" then reached western Europe around 5,500 BC (7,450 BP) and the Armorican Massif around 5,000 BC (6,950 BP; Blanchet et al., 2010) via Danubian agricultural populations, evidenced by the western extension of the Linear Pottery Culture (i.e. Blicquy-Villeneuve-Saint-Germain, in Marcigny et al., 2010), and particularly in Southern Finistère (Marchand et al., 2006; Marcigny et al., 2010; Tinévez et al., 2015) through a diffusion model estimated at $1 \mathrm{~km} /$ year (Giot et al., 1998). The contact between Mesolithic and Neolithic societies remains poorly documented, and predation practices gradually shifted to a production economy thanks to the domestication of animals and the emergence of agriculture. For many years, these cultural changes have been debated as the result of i) the acculturation of indigenous hunter-gatherer populations, or ii) a population replacement by Neolithic societies coming from the East. Recent genetic studies conducted on European populations suggest a Mesolithic population replacement, nevertheless highlighting a mosaic of scenarii according to regions, and a non-uniform demographic transition across Europe with few evidences of cultural adoption (Sampietro et al., 2007 ; Bramanti et al., 2009 ; Haak et al., 2010; von Cramon-Taubadel and Pinhasi, 2011 ; Skoglund et al., 2012). Western Europe population increased sharply as a result of increasing food production. Perennial settlements of Neolithic villages are observed in western France from the first centuries of the $5^{\text {th }}$ millennium BC (around 7,000 to 6,700 BP) (Marchand, 2014).

Considering the emergence of agriculture, palynological and palaeobotanical data are very rare in Finistère. Some studies carried out over Brittany are mainly based on lithic industries and funeral practices (Marchand, 2005), and the beginning of the neolithisation thus cannot be precisely dated, such as in other parts of Europe (Kirleis et al., 2012; McClatchie et al., 2014). In the coastal Morbihan (Locmariaquer, SE Brittany), Visset et al. (1996) suggested ancient cereal farming occurred around 7,243-5,800 BC (9,193-7,750 BP) because of cereal pollen grain occurrences in Mesolithic levels, observed concomitantly with increases of 
ruderal plant and Corylus percentages, as well as a marked decrease of other arboreal pollen taxa. Other palynological studies also discussed the presence of cultivated taxa since the Mesolithic in SE Brittany and around the Loire valley (Barbier and Visset, 1997; Ouguerram and Visset, 2001; Visset et al., 2002; Joly and Visset, 2005). However, the absence of agricultural tools in archaeological sites in the direct vicinity of the above-mentioned sites did not allow confirming these assumptions based on palynological observations (Marchand, 2005). Since the early Neolithic, anthropogenic environmental disturbances and evidences of cereal-cropping became more and more prevalent (Visset, 1979; Marguerie, 1991). In Finistère, the cereal cultivation practice is attested from $3,500 \mathrm{BC}(5,450 \mathrm{BP})$ by the presence of cereal grains in the archeological site of Molène island (Dréano et al., 2007). On the other hand, human impact on the environment becomes noticeable from the first half of the 5th millennium $\mathrm{BC}$ with the first appearance of grindstones and more particularly with traces detected on lithic furniture typical from the cutting of plant fibers (Giot et al., 1998; Guéret et al., 2014).

\section{Material and methods}

\subsection{Study sediment cores}

Pictures and RX radiography were carried out at the Géosciences Marines laboratory (IFREMER, Plouzané, France) for the three study cores (Fig.1), and description, granulometric analyses (laser granulometer "MASTERSIZER 2000”), as well as sampling for AMS ${ }^{14} \mathrm{C}$ dates and palynological analyses were carried out at the Géosciences Océan laboratory (LGO-IUEM, Plouzané, France). All dates (Table 1) have been calibrated with the CALIB 7.1 program using the Marine13 calibration curve (Stuiver and Reimer, 1993; Reimer et al., 2013) and a $\Delta \mathrm{R}$ of $-40 \pm 23$ years (Mangerud et al., 2006). In the manuscript, when referred to a precise age, the mention to "Cal." will not systematically be written, and ages in 
"years BP" or "years BC" will often be both specified so as to facilitate the lecture of the results for paleoenvironmental or archeological communities, respectively.

Within the BD, core "VC2012-08-PQP" (48 ${ }^{\circ} 10.2^{\prime} \mathrm{N}, 04^{\circ} 26.4^{\prime} \mathrm{W}$; $28 \mathrm{~m}$ depth; $486 \mathrm{~cm}$ length; Fig. 1b, 3, 4) was recovered with a vibrocorer by the R/V Pourquoi Pas? during the ProteusDunes cruise (Shom, 2012). Within the BB, core "A" $\left(48^{\circ} 19.2^{\prime} \mathrm{N}, 4^{\circ} 31.8^{\prime} \mathrm{W}\right.$; $8.2 \mathrm{~m}$ depth; $418 \mathrm{~cm}$ length in total but $318 \mathrm{~cm}$ available for this study: the top $100 \mathrm{~cm}$ were entirely used in 2003-2004 by biologists and bio-geochemists) was retrieved in the Bay of Roscanvel (i.e. small bay in the western part of the BB; Fig. 1c, 5) also with a vibrocorer by the R/V Cotes de la Manche during the "Défis Golfe de Gascogne" program (IFREMER, LEMAR-IUEM,

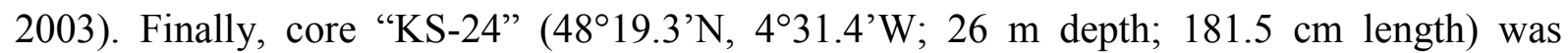
retrieved in the Bay of Roscanvel (BR; Fig. 1c, 5) with a gravity corer by the R/V Thalia during the "SERABEQ 3" cruise (IFREMER, 2015).

\begin{tabular}{|c|c|c|c|c|c|c|}
\hline Lab code & Depth $(\mathrm{cm})$ & material & Age ${ }^{14} \mathrm{C}$ & Error & $\begin{array}{l}\text { Age Cal. BP } \\
\text { Min-max } \\
\text { (mean) }\end{array}$ & $\begin{array}{c}\text { Age } \\
\text { Cal.AD/BC }\end{array}$ \\
\hline \multicolumn{7}{|l|}{ Core VC08 } \\
\hline Poz-85161 & 20 & Gastropod & 1210 & 30 & $\begin{array}{c}702-894 \\
\text { (798) }\end{array}$ & 1152 AD \\
\hline SacA47754 & 23.5 & Bivalve & 635 & 30 & $\begin{array}{l}257-420 \\
(338.5)\end{array}$ & 1611.5 AD \\
\hline SacA47756 & 103 & Bivalve & 7905 & 45 & $\begin{array}{c}8313-8524 \\
(8418.5)\end{array}$ & $6468.5 \mathrm{BC}$ \\
\hline SacA47755 & 158 & Bivalve & 8025 & 40 & $\begin{array}{c}8401-8628 \\
(8514.5)\end{array}$ & $6564.5 \mathrm{BC}$ \\
\hline SacA43117 & 240 & $\begin{array}{c}\text { Acanthocardia } \\
\text { sp. }\end{array}$ & 8030 & 35 & $\begin{array}{c}8410-8625 \\
(8517.5)\end{array}$ & 6567.5 BC \\
\hline SacA43118 & 266.5 & Bivalve & 8060 & 35 & $\begin{array}{c}8433-8688 \\
(8560.5) \\
\end{array}$ & $6610.5 \mathrm{BC}$ \\
\hline SacA43119 & 337.5 & Bivalve & 8090 & 30 & $\begin{array}{c}8483-8737 \\
(8610)\end{array}$ & $6660 \mathrm{BC}$ \\
\hline SacA49420 & 345 & Bivalve & 8105 & 35 & $\begin{array}{c}8492-8774 \\
(8634.5)\end{array}$ & $6684.5 \mathrm{BC}$ \\
\hline SacA43120 & 375.5 & Bittium sp. & 8580 & 60 & $\begin{array}{c}9091-9435 \\
\text { (9263) }\end{array}$ & $7313 \mathrm{BC}$ \\
\hline
\end{tabular}




\begin{tabular}{|c|c|c|c|c|c|c|}
\hline SacA43115 & 405 & Spisula sp. & 8960 & 35 & $\begin{array}{c}9532-9827 \\
(9679.5)\end{array}$ & 7729.5 BC \\
\hline SacA43121 & 408 & Ostrea sp. & 8950 & 35 & $\begin{array}{c}9527-9810 \\
(9668.5)\end{array}$ & $7718.5 \mathrm{BC}$ \\
\hline \multicolumn{7}{|l|}{ Core KS24 } \\
\hline Poz-78151 & 102.5 & Gastropod & 8410 & 50 & $\begin{array}{c}8938-9247 \\
(9092.5)\end{array}$ & 7142.5 BC \\
\hline Poz-78152 & 173.5 & Gastropod & 8530 & 50 & $\begin{array}{c}9045-9383 \\
(9214)\end{array}$ & 7264 BC \\
\hline \multicolumn{7}{|l|}{ Core A } \\
\hline Poz-42799 & $18-19$ & $\begin{array}{c}\text { Venerupis } \\
\text { senegalensis }\end{array}$ & 4930 & 35 & $\begin{array}{c}5221-5445 \\
(\mathbf{5 3 3 3})\end{array}$ & 3383 BC \\
\hline SacA49424 & 46 & Turritella sp. & 5390 & 30 & $\begin{array}{c}5704-5899 \\
(\mathbf{5 8 0 1 . 5 )}\end{array}$ & 3851.5 BC \\
\hline SacA41585 & 70 & Bivalve & 5375 & 30 & $\begin{array}{c}5686-5890 \\
(\mathbf{5 7 8 8 )}\end{array}$ & $3838 \mathrm{BC}$ \\
\hline SacA43114 & $109-110$ & Venus sp. & 5540 & 40 & $\begin{array}{c}5873-6114 \\
(5993.5)\end{array}$ & $4043.5 \mathrm{BC}$ \\
\hline Poz-42840 & $\begin{array}{l}114.5- \\
116.5\end{array}$ & $\begin{array}{c}\text { Venerupis } \\
\text { senegalensis }\end{array}$ & 5580 & 35 & $\begin{array}{c}5911-6149 \\
(\mathbf{6 0 3 0 )}\end{array}$ & 4080 BC \\
\hline Poz-42841 & 161 & Dosinia lupinus & 5690 & 40 & $\begin{array}{c}6005-6258 \\
(\mathbf{6 1 3 1 . 5 )}\end{array}$ & 4181.5 BC \\
\hline Poz-42842 & 187 & $\begin{array}{c}\text { Patia } \\
\text { rhomboides }\end{array}$ & 5790 & 40 & $\begin{array}{c}6159-6365 \\
(\mathbf{6 2 6 2 )}\end{array}$ & $4312 \mathrm{BC}$ \\
\hline SacA41583 & $190-191$ & Bivalve & 5715 & 30 & $\begin{array}{c}6059-6273 \\
(6166)\end{array}$ & $4216 \mathrm{BC}$ \\
\hline SacA41584 & $190-191$ & $\begin{array}{l}\text { Organic matter } \\
\text { For the } \\
\text { reservoir age }\end{array}$ & 5350 & 60 & $\begin{array}{c}5993-6280 \\
(6136.5)\end{array}$ & 4186.5 BC \\
\hline Poz-42843 & $229-231$ & $\begin{array}{c}\text { Venerupis } \\
\text { senegalensis }\end{array}$ & 5900 & 40 & $\begin{array}{c}6264-6457 \\
(6360.5)\end{array}$ & 4410.5 BC \\
\hline SacA41581 & $248-249$ & Bivalve & 5990 & 30 & $\begin{array}{c}6335-6557 \\
(6443)\end{array}$ & 4496 BC \\
\hline SacA41579 & 258 & Bivalve & 5960 & 30 & $\begin{array}{c}6303-6508 \\
(6405.5)\end{array}$ & $4455.5 \mathrm{BC}$ \\
\hline SacA41580 & 297 & Bivalve & 6105 & 30 & $\begin{array}{c}6464-6677 \\
(6570.5)\end{array}$ & 4620.5 BC \\
\hline Poz-42844 & 316 & $\begin{array}{c}\text { Venerupis } \\
\text { senegalensis }\end{array}$ & 6155 & 35 & $\begin{array}{c}6510-6744 \\
(6627)\end{array}$ & 4677 BC \\
\hline
\end{tabular}

278 Table 1: carbon dates made on VC-08, A and KS-24 cores. The $190 \mathrm{~cm}$ level on core A, dated

279 from continental organic matter, is not considered in the age model. It was duplicated from

280 the level $190 \mathrm{~cm}$ dated on bivalve to estimate the reservoir age in the Bay of Brest. 
Palynological preparations were carried out at the EPOC laboratory (University of Bordeaux,

283

Talence), following the procedure described by de Vernal et al. (1999) and using chemical (cold $\mathrm{HCl}$ and cold $\mathrm{HF}$ ) and physical (sieving through a $10 \mu \mathrm{m}$ nylon mesh screen) treatments in order to remove the mineral fraction and to concentrate palynomorphs (cf. http://www.epoc.u-bordeaux.fr/index.php?lang=en\&page=eq_paleo_protocoles). The final residue was mounted between slide and coverslip with glycerin. Pollen and dinocysts were determined using an optical microscope Leica DMC 2900 at X630 magnification.

In this study, 89 samples (46 for core "A", 4 for core KS-24 and 39 for core VC-08) were analyzed allowing to obtain a study resolution of about 20 to 30 years. Palynomorph identification followed Beug (1961), Faegri and Iversen (1989), Moore et al. (1991) and Reille (1995) for pollen and Rochon et al. (1999) for dinocysts. For each analyzed sample, a minimum of 300 pollen grains and 150 dinocysts have been counted in order to provide robust assemblages from a statistical point of view (Fatela and Taborda, 2002). Percentages were calculated on a sum of total pollen grains, or a sum of total dinocysts, without any exclusion. Concentrations (number of specimens $/ \mathrm{cm}^{3}$ ) were obtained thanks to the Lycopodium spore method (Mertens et al., 2009). Through a camera connected to the optical microscope, measurements were also performed on the size of the annulus and of the diameter of Poaceae grains along the VC-08 core so as to differentiate Cerealia from wild grasses (Leroyer et al., 2004; Joly et al., 2007). Finally, other palynomorphs were counted, including microalgae, foraminiferal linings, spores and copepod eggs. 
Prior to the palynological treatments, bulk sediments were sieved at $150 \mu \mathrm{m}$, and the fraction

$>150 \mu \mathrm{m}$ was used for foraminiferal analyses. After dividing the largest samples with a micro-splitter, benthic foraminiferal assemblages were analyzed with a LEICA M60 binocular stereo zoom microscope at X60 magnification. Identification followed WoRMS Editorial Board (2017) (www.marinespecies.org). Data were expressed in percentages of total benthic foraminiferal counts (at least 100 specimens counted per level). 16 samples (12 for core "A" and 4 for core KS-24) were analyzed allowing a resolution of about 150 years.

Monospecific stable oxygen and carbon isotopes were also measured for core " $\mathrm{A}$ " on the Elphidium aculeatum benthic species, in the same levels than benthic foraminiferal assemblages. About five specimens were hand-picked in the 150-250 $\mu \mathrm{m}$ sediment fraction, cleaned in a methanol ultrasonic bath for a few seconds, then roasted under vacuum at $380{ }^{\circ} \mathrm{C}$ for $45 \mathrm{~min}$ to remove organic matter, prior to isotopic analyses (Duplessy, 1978). The $\delta^{18} \mathrm{O}$ and $\delta^{13} \mathrm{C}$ (expressed in \%o VPDB) were measured at the PSO (IUEM, BREST) using the IRMS platform: a Delta V mass-spectrometer coupled with a GasBench II preparation line for benthic species. The external reproducibility $(1 \sigma)$ of an internal standard calibrated with NBS19 is $\pm 0.03 \%$ and $0.06 \%$ for $\delta^{13} \mathrm{C}$ and $\delta^{18} \mathrm{O}$ respectively.

\section{Sedimentary context and palynological results}

\subsection{Bay of Douarnenez, BD (core VC-08)}

\section{Sedimentary facies and age model}

The sedimentology, granulometry and magnetic susceptibility analyses (Fig. 3, 4), core VC08, taken from a BD palaeo-valley (Fig. 1b) highlight different sedimentary deposits that can be related to the sediment units defined in the framework of the study of the sedimentary infilling history of the BD (Le Roy and Jouet, 2005; Fig. 2). 
The base of core VC-08 (from 474 to $425 \mathrm{~cm}$ ) is made of coarse sands (mean granulometry of about $1,500 \mu \mathrm{m}$ ) with high magnetic susceptibility (MS) values illustrating a strong detrital terrigenous component (Fig. 4a), that can be related to units 1 and 2 (U1 and U2 of Le Roy and Jouet, 2005; Fig. 2, 4b) and interpreted as fluvial deposits during the last glacial period. Between 425 and $340 \mathrm{~cm}$, granulometry oscillates from coarse silts to very fine sands marked by a large grain-size variability (from 5 to around $1,500 \mu \mathrm{m}$; Fig. 4a,b), and a fairly high concentration of broken bivalve shells, therefore probably reflecting high energetic conditions. The drop of MS values is related to major environmental change from continental to marine influences, with the sea starting to reach the westernmost part of the channels around 10,000 years BP. This interval can be associated to units 3 and 4 (U3 and U4 of Le Roy and Jouet, 2005; Fig. 2, 4b). Between 340 and $30 \mathrm{~cm}$, clayey sediments (mean granulometry of $10 \mu \mathrm{m}$; Fig. 4a,b) and tidal laminae dominate sedimentary facies. After a small increase, MS values gradually decrease from $250 \mathrm{~cm}$ to the top (Fig. 4a). This very thick deposit constitutes most of the sedimentary infilling of BD channels and corresponds to unit 5 (U5 of Le Roy and Jouet, 2005; Fig. 2, 4b). The last sedimentological deposit (30 cm upwards), delimited at its base by an erosive surface, is characterized by marine sands (mean granulometry of $100 \mu \mathrm{m}$, three main modes between 10 and 1,000 $\mu \mathrm{m}$; Fig. 4a,b) reworked and remobilized under the action of waves. Extremely low MS values suggest the scarcity of fluvial detrital inputs within the bay. This deposit is related to the last unit 6 (U6 of Le Roy and Jouet, 2005; Fig. 2, 4b).

Radiocarbon dates have been obtained on bivalve and gastropod shells (Table 1). The age model (Fig. 6a) was then established from two linear regressions and 9 stratigraphic pointers considering two parts obviously distinct considering the description of the core (Fig. 4b, 6a). A significant change in sedimentation rates is therefore observed around 8,600 years BP (i.e. $340 \mathrm{~cm}$ ), related to the Holocene sedimentary infilling history, with $0.06 \mathrm{~cm} / \mathrm{yr}$ calculated 
before 8,600 years BP and $1.2 \mathrm{~cm} / \mathrm{yr}$ calculated after (Fig. 4, 6a). Two additional dates obtained in the uppermost part of the core (i.e. 20 and $23.5 \mathrm{~cm}, 798$ and $338.5 \mathrm{BP}$, respectively; Fig. 4b) confirm the recent set up of the last unit made of reworked marine sands (U6 in Le Roy and Jouet, 2005). These two dates were therefore not used to build the age model (Fig. 6a). The palynological study is conducted on the fine intertidal sedimentation section of the core, corresponding to units U4 and U5 described by Le Roy and Jouet (2005) (Fig. 3, 4b) and ranging from 390 to $30 \mathrm{~cm}$ (i.e. 9,400 to 8,400 years BP or 7,450 to 6,450 years BC), thus providing information on the final Mesolithic.

\section{$\underline{\text { Dinocysts }}$}

A total of 18 taxa were recognized with an average of nine different taxa per slide. Only main taxa (i.e. greater than $2 \%$ at least once in palynological spectra) were plotted on Fig. 7a along with concentrations (cysts $/ \mathrm{cm}^{3}$ ) and specific richness (number of different taxa per slide). Taken as a whole, Spiniferites bentorii (50 \% in average) and Lingulodinium machaerophorum (11\%) are the most abundant taxa as it is usually described on Brittany's coasts (Morzadec-Kerfourn, 1977; Lambert et al., 2017). The variations of the dinocyst assemblages enable to highlight three main zones, with very low diversity values at the base of the record (VC-A, 390-345cm), followed by a slow increase up to $250 \mathrm{~cm}$ (VC-B, 345-250 $\mathrm{cm}$ ), and higher values over the entire second half of the core (VC-C, 250-30 cm). Diversity then shifts from around 5 to 12 different taxa per slide. In addition to the low dinocyst specific richness, VC-A palynozone is defined by atypical elevated percentages of Achomosphera spp., suddenly replaced by $S$. bentorii. The VC-A / VC-B boundary is well marked in dinocyst assemblages by the occurrences of Spiniferites mirabilis, Spiniferites ramosus and Spiniferites delicatus. Moreover, palynozone VC-B corresponds to increasing percentages of $L$. machaerophorum and a slow decrease of S. bentorii ones. Finally, palynozone VC-C 
corresponds to a disappearance of $S$. mirabilis simultaneously observed with decreasing percentages of Selenopemphix quanta, and the first occurrence of Spiniferites lazus found in the study core (Fig. 7a). Moreover, these biozones are highly related to the variations of dinocyst concentrations.

\section{$\underline{\text { Pollen }}$}

A total of 33 taxa were recognized with an average of 12 different taxa per slide. This rather low diversity due to the forest taxa dominance differs from the greater diversity observed in more recent Bay of Brest pollinic sequences (e.g. Lambert et al., 2017, 2018) and resulting from the herbaceous diversification accompanying the significant anthropogenic landscape opening. In addition to the taxa characterized by percentages found at least once above $2 \%$ in assemblages, some scarce but meaningful elements of the vegetation (i.e. Alnus, Cerealiatype) are plotted on Fig. 7b. In general, percentages of tree pollen grains are relatively stable then representing the most abundant vegetation group (average of $90 \%$ ). They are predominantly represented by Quercus (42\%) and Corylus (33\%), both taxa being then logically anti-correlated all along the core, and accompanied by low percentages of Pinus, Ulmus, Betula and Alnus. Among herbaceous plants, Chenopodiaceae are clearly dominant (7 $\%)$ as well as Poaceae (2\%).

The overall diagram displays weak variations along the core except for total pollen concentrations and diversity that allow identifying two parts corresponding first to both VC-A and VC-B palynozones described from the dinocysts (that we will refer to palynozone VCA\&B in the following description) and, second, to VC-C palynozone (Fig. 7b). The limit between VC-A\&B and VC-C is more specifically marked by a sharp increase in pollen concentrations and specific richness. Palynozones VC-A\&B also correspond to a decreasing trend of Corylus, correlated to a Pinus increase, then replaced by Quercus. In parallel, the pollen specific richness tends to increase. The palynozone $\mathrm{VC}-\mathrm{C}$ is marked by oscillations of 
the two major taxa, Corylus and Quercus, up to 30\%, contrasting with the lower part of the diagram. Concentration peaks (dotted lines in Fig. 7b) correspond to increases of Corylus percentages and related decreases of Quercus ones. In addition, a decrease of Ulmus is noticed throughout the sequence, along with a slight increase of herbaceous plants (e.g. Poaceae, Asteraceae, Brassicaceae). Also, Cerealia-type are more pronounced in palynozone VC-C. We can note again the overlap between biozones and variations in pollen concentration, as for dinocysts.

\section{Towards a Holocene sedimentary infilling history reconstruction of the BD}

The sedimentological and palynological analyses conducted on core VC-08 (depicted in depth in Fig. 7 and in age in Fig. 8) allow to clarify the sedimentary infilling model discussed by Jouet et al. (2003) and Le Roy \& Jouet (2005).

From 474 to $420 \mathrm{~cm}$ (Fig. 4b), sediments are too coarse to be sampled for palynological analysis. This part could be related to the bedrock incision by rivers during the end of the last glacial period (U1 and U2; Fig. 2), as also evidenced in our study by high magnetic susceptibility (MS) values (Fig. 4a). Palynological results highlight a high Pollen/Dino ratio from 390 to $340 \mathrm{~cm}(8,630$ years BP) (palynozone VC-A; Fig. 8) suggesting a major pollen contribution of surrounding watersheds and therefore predominant fluvial versus marine inputs, corresponding then to the fluvial deposits (fluvial accretion bars of U3-U4 in Le Roy and Jouet, 2005; Fig. 2 and 4b). The Chenopodiaceae content (Fig. 7b) is likely a clue of the already settled salt-marshes. Still discrete marine influences do not allow dinoflagellates to occur in large number during palynozone A, the study core being located upstream in the palaeo-river network incising the substratum of the BD (Fig. 1b). Unfortunately, the ecology 
of Achomosphera spp. is not precisely known and the taxa thus cannot be connected to particular ecological conditions at that time.

From 340 to $250 \mathrm{~cm}(8,630$ to $8,550 \mathrm{BP}$, palynozone VC-B, Fig. 7 and 8, lower part of U5 in Fig. 4b) the marine influence is first marked by the increased dinocyst diversity, including euryhaline taxa such as L. machaerophorum and S. belerius, together with taxa more characteristic of marine environments such as $O$. centrocarpum, S. delicatus, S. mirabilis and S. ramosus (Morzadec-Kerfourn, 1977, 1979). In parallel, decreasing percentages of the typically coastal species $S$. bentorii is probably more related to increasing percentages of the other taxa. The lower part of U5 corresponds to a thick transitional sequence between continental and marine influences, submitted to the relative sea-level rise as observed through the continuous decrease of the Pollen/Dino ratio (Fig. 8). The already mentioned breakdown in sedimentation rates at $340 \mathrm{~cm}$ (limit between U4 and U5; Fig. 4, 6a) corresponds to this major transition towards an estuarine sedimentation. Variations in particle size and in sediment facies are also obvious through the sudden jump in MS values, indicating greater continental intakes from 8,600 years BP (Fig. 4a, 10).

From $250 \mathrm{~cm}$ (palynozone VC-C in Fig. 7 and 8, U5 upper part in Fig. 4b), marine influences are well established with a low Pollen/Dino ratio (Fig. 8), a high dinocyst diversity and the persistence of typically coastal (i.e. S. bentorii) and marine (i.e. cysts of $P$. dalei, $O$. centrocarpum, S. membranaceus, $S$. delicatus) dinocyst taxa, already observed in the previous zone (Fig. 7a). L. machaerophorum, often associated to fluvial and estuarine brackish environments (Marret and Zonneveld, 2003), displays percentages that exceed the average of its whole dataset (Fig. 7a) and are anti-correlated with $S$. bentorii and/or O. centrocarpum (i.e. more related to the oceanic domain; Morzadec-Kerfourn, 1976, 1979) ones. 
Palynological studies conducted on core VC-08 therefore confirm the environment sketches proposed by Le Roy and Jouet (2005) on the basis of sedimentological and seismic data. Furthermore, an obvious major limit can be defined within the tidal facies of U5 at 8,550 years BP, with a lower transitional part under increasing marine influences, and an upper part characterized by well-established marine conditions in a perennial flooded bay.

\subsection{Western Bay of Brest (A and KS-24 cores Bay of Roscanvel)}

\section{$\underline{\text { Sedimentary facies }}$}

Core "A" (Fig. 5a) is characterized by clayey sediments and numerous shell debris (Fig. 5b) as well as bivalve and gastropod shells in life position often sampled for dating. The age model (Fig. 6b) was established through a linear regression between 13 AMS ${ }^{14} \mathrm{C}$ dates (Table 1) allowing to consider an interval of about 1,400 years $(6,700$ to 5,300 BP or 4,750 to 3,350 BC) and mean sedimentation rates of about $0.26 \mathrm{~cm} / \mathrm{yr}$ (Fig. 6b). Palynological analyses have been conducted along the $318 \mathrm{~cm}$ of the core. It is worth noting that in one sample, the 190$191 \mathrm{~cm}$ level (Table 1), continental organic matter (vegetal fibers) has been dated in parallel with a bivalve for obtaining an estimation of the age reservoir within the Bay of Brest. When calibrating the ${ }^{14} \mathrm{C}$ ages with IntCal13 without assuming any age reservoir effect on the marine carbonate material, we obtain a difference of about 357 years between both dates, thus indicating a $\Delta \mathrm{R}$ of -43 years, very close to the one calculated by Mangerud et al. (2006) off the Sein Island (i.e. $\Delta \mathrm{R}$ of $-40 \pm 23$ years) (http://calib.org/marine/).

Regarding core KS-24 (Fig. 5a), sampled in a deeper but closed site, the basal part is characterized by clayey sediments sampled for palynological analyzes, and the upper part consists in coarse sands and shell debris (Fig. 5c). These two parts of the core are separated by a well-marked erosive surface at around $100 \mathrm{~cm}$ depth. Two AMS ${ }^{14} \mathrm{C}$ dates carried out at 
173.5 and $102.5 \mathrm{~cm}$ allow dating the clayey section (i.e. interval sampled for palynological analyzes; Fig. 5c) between 9,214 and 9,092 years BP (7,264 and 7,142 years BC).

\section{$\underline{\text { Dinocysts }}$}

In both cores, 24 different taxa were identified, with an average of three different taxa per slide for core KS-24 and 12 for core "A". Similar to core VC-08, only main taxa were plotted on Fig. 9a along with dinocyst concentrations and the specific richness. These two cores constitute two temporal windows (i.e. 9,200-9,000 years BP for core KS-24, and 6,700-5,300 years BP for core "A") on the same study site (i.e. Bay of Roscanvel, westernmost part of the Bay of Brest; Fig. 1c). Both cores are described together, in their stratigraphical order, core KS-24 representing a palynozone by itself.

Core KS-24 is characterized by the largely dominant S.bentorii species (69 \%; Fig. 9a), similar to the BD at the same period (Fig. 7a). Co-occurring with cysts of P. dalei, O. centrocarpum, S. membranaceus and S. quanta at the base, S. bentorii becomes monospecific at the top of core KS-24. From the base to the top of core "A", dominant taxa are first characterized by cysts of $P$. dalei, then replaced by L. machaerophorum that reach about 80 $\%$. Decreasing percentages of cysts of $P$. dalei and S. ramosus are consequently observed at the same time. Variations in percentages of major species and in total concentrations allow us to delimit three palynozones (two of them being subdivided in two sub-palynozones). First palynozone A-A (from 318 to $250 \mathrm{~cm}$, Fig. 9a) displays a significant increasing trend of cysts of $P$. dalei, a decreasing trend of L. machaerophorum and high percentages of S. ramosus and S. membranaceus. At the limit between A-A and A-B, total cyst concentrations as well as $L$. machaerophorum percentages show their lowest values, while cysts of $P$. dalei reach its highest percentages (i.e. around $50 \%)$. Second palynozone A-B $(250-100 \mathrm{~cm})$ is well marked by noticeable opposite trends, and especially by increasing percentages of $L$. 
machaerophorum and decreasing ones of cysts of $P$. dalei. Then $S$. bentorii displays higher values than in the previous zone, while $S$. ramosus displays lower percentages. Moreover, palynozone A-B corresponds to the strongest occurrences of S. lazus. This palynozone has been divided into two sub-palynozones. Within zone A-B1, L. machaerophorum percentages are the lowest while those of cysts of $P$. dalei are the highest of their respective whole datasets. L. machaerophorum occurrences gradually rise in zone A-B2 and S. bentorii percentages stabilize with a plateau of high percentages during this interval. The third palynozone A-C (from $100 \mathrm{~cm}$ onwards; Fig. 9a) corresponds to a huge increase of $L$. machaerophorum percentages while those of cysts of $P$. dalei sharply decrease, together with a drop of S. ramosus. An additional subdivision is proposed to highlight the abrupt increase in dinocyst concentrations at $50 \mathrm{~cm}$ (limit between A-C1 and AC-2). Furthermore, within zone A-C1, weak but significant occurrences of $S$. membranaceus and $S$. mirabilis are observed, while percentages of cysts of P. dalei, S. mirabilis, but also S. ramosus, and S. lazus drop to extremely low values within zone A-C2. Conversely, O. centrocarpum and S. belerius slightly increase in last zone A-C2.

\section{$\underline{\text { Pollen }}$}

In both cores, 34 different taxa were recognized with an average of 11 different taxa per slide for core KS-24 core and 12 for core "A" (Fig. 9b). While the two major taxa are the same for both cores (i.e. Corylus and Quercus), pollen concentrations are much higher in core KS-24 $(9,200-9,000$ years BP) than in core "A" $(6,700-5,300$ years BP). Furthermore, trees are much more present in core "A" than in the core "KS-24 (i.e. $93 \%$ vs. $79 \%$ ). Among the herbaceous in the core KS-24, Chenopodiaceae are particularly represented with an average of $12 \%$. 
In core "A", increasing percentages of Alnus (from $0 \%$ to $15 \%$ ), and decreasing trends of Ulmus and Tilia, allow to delimit the same palynozones than those described for dinocysts (Fig. 9a). In general, herbaceous plants are very rare but a slow diversification is observed towards the top, with the appearance of some minor taxa (e.g. Ranunculaceae, Mercurialis, Plantago spp., Caryophyllaceae). Corylus and Quercus are anti-correlated throughout the core. More specifically, the first palynozone A-A (318 to $250 \mathrm{~cm}$; Fig. 9b) corresponds to low percentages of Corylus that gradually increase at the end of the palynozone and, conversely, to high percentages of Quercus that tend to gradually decrease. During this interval, Tilia and Poaceae represent a meaningful part of the pollen content. Second palynozone A-B (250 to $100 \mathrm{~cm}$ ) displays the occurrence and rise of Alnus, as well as the noticeable decrease of both Poaceae and Tilia. Furthermore, at the start of palynozone A-B, Ulmus and Pinus percentages exhibit stable values when compared with palynozone A-A, while they suddenly drop around $200 \mathrm{~cm}$, allowing to discriminate sub-palynozones A-B1 (from 250 to $200 \mathrm{~cm}$ ) and AB2 (from 200 to $100 \mathrm{~cm}$ ). Conversely, Alnus percentages strongly increase in sub-palynozone A-B2. Palynozone A-C (from $100 \mathrm{~cm}$ onwards) highlights a new threshold with a marked decrease of Ulmus together with a strong increase in Alnus percentages, the latter reaching its highest values within zone A-C2 in parallel with relatively continuously high pollen concentrations. Interestingly, most of the main peaks observed with pollen concentrations (dotted lines in Fig. 9b) also correspond to increases of Alnus percentages along with high values of Corylus, as already noticed for the VC-08 record.

\section{Micropalaeontological results}

Benthic foraminiferal assemblages are presented in depth for cores "A" and KS-24 (Fig. 10), in parallel to the isotopic data measured on Elphidium aculeatum. Since Elphidium spp. are the dominant taxa, all other taxa percentages have been calculated on a main foraminiferal 
sum that excludes E. crispum and E. aculeatum. Similar to palynological data, only species occurring at least once with percentages above $2 \%$ have been plotted in Fig. 10.

Along core KS-24, foraminiferal concentrations are low and assemblages are dominated by Haynesina germanica (average of about $50 \%$ ), with few Elphidium spp. and important variations of Ammonia spp., here strictly assigned to the species $A$. tepida.

Along core A, an increase of total benthic foraminiferal concentrations is observed throughout the sequence and epifauna are the most represented in benthic foraminiferal assemblages, with Elphidium aculeatum and E. crispum both accounting for $70 \%$. Zones previously described for dinocyts and pollen grains have been reported in the foraminiferal diagram, so as to facilitate the cross-correlated approach between all fossil bio-indicators. Zone A-A is mainly characterized by Elphidium spp. that displays an increasing trend, an important content of Miliolidae, and an abrupt decrease of Cibicides spp. In addition, Ammonia tepida and Planorbulina mediterranensis are observed with significant percentages. Palynozone A-B corresponds to still high Elphidium spp. percentages and occurrences of A. becarii. Within this interval, two subzones correspond first (i.e. A-B1, 250 to $200 \mathrm{~cm}$ ) to decreasing values of Cibicides and Miliolidae, together with the occurrence of Lagena spp., and then (i.e. A-B2, 200 to $100 \mathrm{~cm}$ ) to increasing percentages of Cibicides (reaching 20\%) and drastically low Lagena percentages. Within palynozone A-C (from $100 \mathrm{~cm}$ onwards), A. becarii is replaced by A. tepida, while Cibicides spp., P. mediterranensis and epiphytes (i.e. with a flat face that allow them to be attached to sediments or plants) show approximately a same increasing profile, opposite to the Elphidium spp. trend.

Regarding isotopic analyzes (Fig. 10), $\delta^{13} \mathrm{C}$ and $\delta^{18} \mathrm{O}$ show opposite trends with a slight decrease towards lighter values for the $\delta^{18} \mathrm{O}$ signal (amplitude of 1\%o between minimal and maximal values in the dataset, ranging from $1.8 \%$ o to around $0.8 \%$ ), and a slight increase 
569

570

\section{Environmental evolution in the Bay of Roscanvel (BR) under the rising sea level influence}

573 Environments of the BR were greatly impacted by the relative sea-level rise between 9,000

574 and 5,000 years BP. The general palaeoenvironmental evolution of the BR can be

575 reconstructed thanks to two Holocene windows obtained on core "A" $(6,700-5,400$ years BP)

576 and core KS-24 (9,200-9,090 years BP) and with averaged palynological (pollen and

577 dinocysts) and foraminiferal results compiled in pie charts (Fig. 11).

578 Throughout core KS-24, dinocyst assemblages show a low general diversity with major

occurrences of $S$. bentorii (Fig. 9a, 11), arguing for a strictly coastal environment. Among pollen assemblages (Fig. 9b, 11), core KS-24 displays an important content of Corylus, a species considered as pioneer during the post-glacial temperate forest (mixed oak) reconquest that mainly marked north-western European landscapes around 9,000 years BP (Huntley, 1993; Tinner and Lotter, 2001). Among herbaceous plants, Chenopodiaceae are significantly present, certainly coming from nearby salt-marshes. In addition, foraminiferal assemblages are dominated by Haynesina germanica, Ammonia tepida, and Elphidium williamsoni. A. tepida and E. williamsoni are closely related to intertidal sheltered mudflat environments, while H. germanica is related to continental organic matter inputs (Debenay et al., 2006; Rossi et al., 2011). These three species indicate a highly tidal-influenced environment and local small runoffs rich in continental organic matter (Redois, 1996; Debenay et al., 2006; Perez-Belmonte, 2008; Rossi et al., 2011). However, the noticeable absence of $L$. machaerophorum and Alnus suggests low major freshwater supplies. The surrounding continental context may then correspond to small watersheds, while the Aulne River was still 
593

594

595

596

597

598

599

600

601

602

603

604

605

606

607

608

609

610

611

612

613

614

615

616

617

flowing to the north of core KS-24 location taking into account the low sea level position at that time (i.e. -26 m; Gregoire et al., 2017; Fig. 11). In this context, the marine influence remains confined to the axis of the main channels of the Aulne and Elorn Rivers (Gregoire et al., 2017). The higher river terraces (i.e. where core "A" was taken; Fig. 1c, 5c) are entirely emerged at that time, while the lower site where core KS-24 has been retrieved (Fig. 1c, 5c) is characterized by the development of abundant maritime marshes (schorre and slikke) with halophilous plants (i.e. Chenopodiaceae) and a rather weak fluvial dynamic. Considering the current $26 \mathrm{~m}$ depth location of core KS-24 and its $1.81 \mathrm{~m}$ length, it allows deducing a relative sea-level between 27 and 28 meters under the current sea-level which is very similar to the 26 meters proposed at 9,000 years BP by Gregoire et al. (2017), taking into account the macrotidal context of north-western Brittany.

Throughout core "A", dinocyst assemblages display a general higher diversity than in core KS-24 with 24 taxa, mostly oceanic to coastal, along with occurrences of about $35 \%$ of $L$. machaerophorum (estuarine taxon). Predominant marine influences, favorable for diversified dinoflagellate blooms, are associated to the BR marine flooding in a context of superimposed fluvial influences, as evidenced by L. machaerophorum, mainly associated to Aulne River inputs, here perceptible compared to the previously marsh environment described with core KS-24. Concerning pollen assemblages, the mixed temperate forest is settled $(90 \%$ of tree pollen grains, Fig. 9b and 11) with a higher representation of Quercus when compared to core KS-24. This indicates a connection of the BR to the main stream of the Aulne River due to the flooding of the $\mathrm{BB}$, thus highlighting a more regional signature (i.e. $\mathrm{BB}$ watersheds) in core "A", also corresponding to the colonization of temperate tree taxa in western Europe during the mid-Holocene (Ruddiman and McIntyre, 1981; Brewer et al., 2002). The Chenopodiaceae signal is less pronounced in core " $A$ " due to the disconnection of the study site from marsh environment, as also confirmed by the drastic reduction in marsh-related foraminiferal species 
618 (i.e. Haynesina germanica, Ammonia tepida, and Elphidium williamsoni). Also, benthic

619 foraminiferal assemblages display a stronger diversity in core " $\mathrm{A}$ " suggesting a greater marine

620 influence in agreement with dinocyst results. Moreover, the presence of some epiphytic and

621 fixed species (i.e. Cibicides spp. and Planorbulina mediterranensis) suggests a higher

622 hydrodynamism. In addition, the absence of benthic infauna could indicate a lack of very

623 important organic matter inputs. The environment would therefore be characterized by a

624 sufficient organic matter supply to allow the development of algal coverings (allowing the

625 presence of epiphytes), and hydrodynamism would disperse this organic material, thus

626 oxygenating the bottom. In summary, around 6,000 years BP the relative sea level was

627 relatively close to the present-day one (Goslin et al., 2015) and the BB as a whole (and thus

628 the BR) is flooded (Fig. 11). The environment is then marked by a clearer marine influence

629 and the remoteness of salt-marshes areas. Tidal currents erode sediments on terrace slopes

630 from the main channels, leading to erosive surfaces separating muddy and sandy facies (i.e.

631 upper part of KS-24 core from $100 \mathrm{~cm}$ onwards not sampled for palynological analysis, Fig.

632 5c), as also identified by Gregoire et al. (2017). 


\section{Climate impacts and land-use changes}

\subsection{Local imprints of the 9,000-8,000 and 6,000-5,000 years BP RCC events}

Superimposed on the palaeoenvironmental reconstitutions discussed in the context of the rising sea-level context, climate trends are well expressed in our palynological records due to our high resolution study carried out on cores characterized by high sedimentation rates.

In the Bay of Douarnenez, from 8,550 to 8,400 years BP (zone VC-C; Fig. $7 \mathrm{~b}$ and 12), Corylus becomes clearly dominant. Moreover, this interval displays a slight decrease of Ulmus, a disappearance of the thermophilous taxon S. mirabilis, and significant occurrences of S. lazus, a dinocyst associated with cold SST (Zonneveld et al., 2013). These palynological evidences may support a cooling event. Indeed, this cooling associated with the appearance of a strong seasonal contrast between 8,855 and 8,000 years BP observed by Naughton et al. (2007) favors the development of Corylus woodlands and contributes to the decrease of deciduous Quercus forest expanse. In the same time, the obvious increase of pollen fluxes, coeval with a marked increase of $L$. machaerophorum percentages, and Alnus ones to a lesser extent, may argue for increasing fluvial discharges (as previously discussed in Lambert et al. 2017 ) and thus of humidity. It is worth noting that low percentages of Alnus may here be ascribed to its later settlement in the vegetal reconquest succession, as observed in the Armorican Massif by David (2014). Each L. machaerophorum increase (Fig. 7a and 12), also concomitant to the withdrawal of coastal (S. bentorii) and marine (O.centrocarpum) species, coincides with increasing percentages and concentrations of Corylus (Fig. 7b and 12).

In the Bay of Roscanvel, dinocyst assemblages were dominated by S. ramosus (oceanic taxa; Morzadec-Kerfourn, 1977) and cysts of $P$. dalei before 6,000 years BP, and are characterised after this limit (between zones A-B and A-C) by an obvious and sharp increase of $L$. machaerophorum percentages from 30 to $70 \%$ (Fig. 9a and 12), a species usually 
encountered in estuarine and fluvial environments of Brittany's coasts (Morzadec-Kerfourn, 1977). This could emphasize the establishment of stratified waters related to increasing fluvial inputs. Furthermore, L. machaerophorum is accompanied by increasing percentages of the heterotrophic taxa S. quanta (Fig. 9a) that could support increasing fluvial nutrient inputs to the BB. Moreover, since Alnus began to appear on the territory, we now observe an increase of this tree in parallel with L. machaerophorum. As previously observed for core VC-08, Corylus increases are concomitant with peaks of pollen concentrations and of $L$. machaerophorum percentages. Finally, higher percentages of $H$. germanica and A. tepida (Fig. 10), benthic foraminiferal species subordinate to environments under fluvial influences (Debenay et al. 2006; Perez-Belmonte, 2008; Estournès et al. 2012), confirm previous observations of increasing fluvial discharges probably related to increasing moisture.

For both cores VC-08 and "A", increasing fluvial inputs would correspond to a local detection of the large-scale Holocene millennial-scale climatic variability (i.e. "Bond events", Bond et al. 2001; or RCC for "Rapid Climate Change", Mayewski et al., 2004). Most of these cold Holocene events, initially identified in North Atlantic sedimentary cores by detrital grains drained by glaciers (Fig. 12a), correspond to Scandinavian glacier advances (Nesje et al., 2001), colder northern hemisphere temperatures and drier conditions in the tropics (Mayewski et al., 1997, 2004; Meeker and Mayewski, 2002). Also, the strengthening of the westerlies (Bradbury et al., 1993; Mayewski et al., 2004) may have resulted in recurrent positive modes of the NAO, leading to increased precipitations in north-western Europe. Interestingly, Mojtahid et al. (2013) associated the 6,000-5,000 interval to persistent positive NAO conditions in the Bay of Biscay. A solar irradiance decline may be responsible for this 6,000 5,000 years BP event (Steinhilber et al., 2009; Fig. 12a), also leading to a North-Atlantic SST decrease (Jiang et al., 2015; Fig. 12a). Thus, cores VC-08 around 8,550 years BP, and core "A" around 6,000 years BP (Fig. 12c), may then evidence for the first time the regional 
683 imprint in western Brittany's coasts of two RCC events through significant increases in moisture and fluvial discharges.

\subsection{Local signal of Cerealia-type pollen grains during the Mesolithic: coastal Poaceae or}

687

688

689

690

691

692

693

694

695

696

697

698

699

700

701

702

703

704

\section{early traces of a proto-agriculture?}

Between 8,600 and 8,300 years BP, VC-08 core shows a very homogeneous laminated facies which attests to a stable environment aggradation related to a deltaic alluvial plain characterized by intertidal regimes (Le Roy and Jouet, 2005; Fig. 4). Constant percentages of Chenopodiaceae all along the record, associated with few and constant percentages of Poaceae (Fig. 7b), suggest a coastal marsh (slikke and schorre-type) environment, confirming the aggradation of intertidal deposits. In this sedimentary context, the palynological analysis interestingly records iterative occurrences of large pollen grains of Poaceae (Fig. 13).

Cereal pollen identifications are usually based on the diameter criteria (grain and annulus) following Beug (1965), Leroyer et al. (2004) and Joly et al. (2007), because of the impossibility to separate wild grasses and Cerealia-type pollen grains using exine sculpture types (Beug, 2004). In western Europe, the commonly accepted thresholds of $45 \mu \mathrm{m}$ for the grain diameter and $8 \mu \mathrm{m}$ for its annulus (that we will refer as the $45-8 \mu \mathrm{m}$ criteria) theoretically enable the distinction between cereal pollen grains and those of indigenous wild grasses from the French western Atlantic coast (Leroyer et al., 2004). Considering these criteria along the whole sequence, 7 levels delivered cereal-type grains with one to 3 occurrences in palynological slides. These 12 large pollen grains recognized in total, and distributed all along the core $(325,295,220,170,140,120$ and $65 \mathrm{~cm}$, Fig. 13), have been carefully measured, providing average values of $46 \mu \mathrm{m}$ for the grain diameter and $9.9 \mu \mathrm{m}$ for the annulus. Nevertheless, the " $45-8 \mu \mathrm{m}$ " criteria have been criticized (Joly et al., 2007). The 
statistical study conducted by Joly et al. (2007) on modern plants from the Atlantic coast reveals that a " $45-10 \mu \mathrm{m}$ " criteria makes it possible to identify $91 \%$ of cereals (but $9 \%$ of pollen grains are from wild grasses). In their study, Joly et al. (2007) then proposed to increase the thresholds to a most discriminant level of " $47-11 \mu \mathrm{m}$ ", thus avoiding to consider, as much as possible, larger pollen grains of coastal grasses from the Atlantic coast. The "47$11 \mu \mathrm{m}$ " criteria then make it possible to discriminate $96 \%$ of cereal pollen grains (i.e. $4 \%$ of wild poaceae fall within this criterion) (Joly et al., 2007). However, with these new criteria, the sensibility to detect Cerealia pollen grains significantly declines. More precisely, among 100 modern Cerealia pollen grains, only 59 would be detected as such with the " $47-11 \mu \mathrm{m}$ " criteria, the other grains being then supposed as wild Poaceae. Despite this low sensibility and the fact that some cereals are probably not taken into account with these thresholds, the applied " $45-11 \mu \mathrm{m}$ " criteria to our data confirm discreet peaks of Cerealia-type pollen grains, from around 8,600 to 8,300 years BP (at 65, 120 and $170 \mathrm{~cm}$; Fig. 13).

Considering that indigenous coastal grasses may have larger pollen grains than continental species, it is also worth noting that these weak occurrences observed in the BD record do not co-occur in parallel with variations of other Poaceae or Chenopodiaceae, suggesting no significant changes in landscape and/or pollen transport at that time. Moreover, to be more confident about these atypical and early observations, many other clues must be considered. Some plants often associated with crops (e.g. adventitious taxa) are necessary to discuss anthropogenic signatures in the vegetation cover (Behre, 1981; Willcox, 2005). It is precisely interesting to note that slight increases in Plantago lanceolata, Rumex sp. and Brassicaceae percentages are observed in VC-08 core during main occurrences of Cerealia-type (Fig. 8 and 14). A slight long-term decrease can also be highlighted in tree percentages between 8,600 and 8,300 years BP, perhaps arguing for an early start of a small human-made landscape opening (Fig. 8 and 14). 
Our findings are however in marked opposition with the regional neolithisation model admitted by the archaeological community and based on clues related to changes in cultural practices identified by lithic (and ceramic) industries (Cassen et al., 1998; Marchand, 2005, 2007; Marchand et al., 2006; Blanchet et al., 2006; Pailler et al., 2007, 2014; Hamon, 2008). In addition, studies on Mesolithic archeological sites in Brittany have highlighted traces of plant cuttings, but tools did not show the classical polishes associated with cereal cuttings (Guéret, 2013; Guéret et al., 2014). Even if our results raise questions and encourage caution, they are consistent with other palynological studies carried out in western France that also evidenced early discreet appearances of Cerealia-type pollen grains (Fig. 15). As early as 1996, analyses conducted by Visset et al. opened the debate about the existence of a very ancient cereal farms as highlighted by low occurrences of Cerealia-type pollen between 7,200 and 5,800 years BC $(9,200-7,800$ years BP), concomitantly with increases of Corylus and ruderal plant percentages and decreasing Quercus percentages in the coastal Morbihan region (SE Brittany; Fig. 15). Other studies along the Loire River revealed the presence of cereal pollen taxa as well as Juglans between 6,400 and 5,900 years BC (8,400-7,900 years BP; Ouguerram and Visset, 2001) and between 6,600 and 5,800 years BC (8,500-7,800 years BP; Carcaud et al., 2000). Moreover, Joly and Visset (2005, 2009) reported cereal and ruderal pollen grains on the southern Atlantic coast (Vendée) between 7,500 and 6,300 years BC (9,500-8,200 years BP) and between 7,500 and 6,200 years BC $(9,400-8,100$ years BP). Beyond Brittany, some early Cerealia-type occurrences have already been observed as cooccurring with ruderal plants between 6,400 and 5,800 years $\mathrm{BC}(8,400-7,800$ years $\mathrm{BP})$ in the northern Pyrenean region by Galop and Vaquer (2004) or between 6,600 and 5,800 years BC (8,600-7,800 years BP) in the Parisian Basin (Leroyer and Allenet, 2006). In addition, occurrences of Cerealia-type pollen grains have been reported from many Swiss sites between 7,750 and 5,800 Cal. BC (Erny-Rodmann et al., 1997; Lotter, 1999; Tinner et al., 
1999, 2007; Beckmann, 2004; Fig. 15). Taking into account our data and the numerous references cited above, we underline the great timing coherence of large Poaceae pollen grain appearances, with sizes usually interpreted as resulting from a cultivated origin. Among the reservations that are often opposed to these detections (e.g. reliability of dating, long-distance transport or laboratory contaminations; Behre, 2007), we can consider minimal errors in carbon datings (see the core stratigraphy) or in laboratory treatments that are identical for all cores (i.e. Roscanvel "A" core, without any large Poaceae pollen grain). Regarding the longdistance transport of pollen grains from the eastern areas where cereals were already cultivated, as already mentioned by Tinner et al. (2007), it is surprising that we do not detect pollen grains from other exotic species with a better pollen dispersion than cereals (e.g. Quercus ilex, Pistacia). Moreover, the BB and BD watersheds are too small to receive longtransported pollen grains from eastern or southern sites. We can thus suggest two hypotheses:

1. These atypical large pollen grains are not inherited from cultures and represent a signature of littoral grasses. Indeed, some coastal Poaceae on the Atlantic coast may have pollen grains that can reach large sizes (Joly et al., 2007). The size threshold which is considered by palynologists as a robust identification criteria for the determination of cereal pollen grains, may be revised again (cf. Joly et al., 2007) in light of the particular pollen sizes of some regional littoral grasses. Regarding this first hypothesis, it still appears curious not to detect any significant increase in total Poaceae or Chenopodiaceae when the most relevant peaks of Cerealia-type pollen grains are recorded (Fig. 7b). Furthermore, in the Bay of Roscanvel records (A and KS-24 cores, Fig. 9b), studied from 9,200 to 5,300 years BP in same environmental sedimentary context, the total absence of these large pollen grains of Poaceae before 8,600 years BP implies no peculiarity of size among pollen grains from littoral grasses.

2. A discreet proto-agriculture signal would be recorded for the first time during the Mesolithic in western Brittany. Discussed by the Mesolithic archaeological community, this 
type of "agriculture" would be characterized by its discretion in the landscape and the absence of specific hard rock made agricultural tools (Marchand, 2005). The work of plants seems indeed to grown toward the end of the Mesolithic, but regional use-wear analysis on archeological material suggested that wear traces result from scrapping of wood and soft plants, with however no traces of cereal plant work (e.g. Gassin et al., 2013; Beg an Dorchen, SW Brittany). In the previous palynological studies mentioned above (Fig. 15), Cerealia-type pollen grain occurrences are always scarce and isolated in space and time (Visset et al., 2002). Our study, conducted on a core taken in the marine coastal domain, enables to record a temporal BD watershed signal with iterative occurrences of these large pollen grains $(8,482$; 8,$440 ; 8,395$ years BP or 6,$532 ; 6,490 ; 6,445$ years BC) associated with some other cultural indicators as Plantago lanceolata and Rumex spp. (Fig. 14). The scarcity of Mesolithic data on the territory, and the difficulties to identify proto-agriculture evidence, both with pollen or lithic data, does not allow to discuss the local introduction of this proto-agriculture imprint as a result from a meridional migration movement (Retzian culture via the Loire estuary; Visset et al., 2002) or from the main Neolithic cultural in Brittany from a Danubian origin (Dubouloz, 2003; Gomart et al., 2015; Fig. 15).

In order to progress, future studies must be conducted i) to newly establish the size variation of the current littoral wild grass pollen grains, ii) to confirm the timing of the first large pollen grain detection at a broader regional-scale. 


\section{Conclusion}

803

804

Our results allowed characterizing Holocene coastal palaeoenvironments of NW France (Bay of Brest and Bay of Douarnenez, western Brittany) over two given periods (9,200-8,400 and 6,600-5,300 years BP). Various factors forced coastal environmental changes during the early to mid-Holocene especially including the relative sea-level rise that modified sedimentation processes and the post-glacial recolonization of temperate trees. Sedimentological and palynological analyses carried out in this study allowed us to characterize and specify the environmental variations that impacted coastal environments of western Brittany. The relative sea-level rise influenced the sedimentary infilling history of shallow marine environments that transited from river valleys to oceanic bays. In addition, high resolution studies enabled us to detect the regional response to more global events arising from the millennial-scale climate variability in the North Atlantic. Thus, around 8,600 and 6,000 years BP, onsets of two major abrupt climate events are locally detected by a moisture increase marked by strong occurrences of Corylus, Alnus, and L. machaerophorum dinocyst taxon. In addition, the gradual decrease of continental summer temperatures is marked by the withdrawal of thermophilous species Ulmus and Tilia. Moreover, during this time period also marked by the appearance of the neolithisation, Cerealia-type pollen grains have been detected in the Bay of Douarnenez, about 1,500 years before the advent of agriculture commonly accepted. These local results, while being consistent with other palynological studies conducted on the French Atlantic coast, must be taken with caution and open the way to further studies so as to confirm these "pre-domestic" agriculture indices. 


\section{Acknowledgements}

824

825

826

827

828

829

830

831

832

833

834

835

836

837

838

839

840

841

842

843

844

845

846

847

This study was supported by the French CNRS and is a contribution to the 2015-2016 INSU project EC2CO-LEFE: «CAMOMI : Convergences / Approches croisées des signaux MOléculaires et MIcropaléontologiques pour décrypter les forçages anthropiques et climatiques en milieu côtier (Rade de Brest) » and the UBO-BQR project: «PARADE: Signature PAléoenvironnementale des séquences holocènes en RADE de Brest ». This work was supported by the «Laboratoire d'Excellence» LabexMER (ANR-10-LABX-19) and cofunded by a grant from the French government under the program «Investissements d'Avenir ». We thank the UMR CNRS 5805 EPOC (Talence) for palynological laboratory procedures (Muriel Georget), the UMS 2572 LMC14 (Saclay) for carbon dating via Artemis project fundings, the sedimentology laboratory of the Shom ("Service Hydrographique et Océanographique de la Marine") for the VC-08 core taken from the Bay of Douarnenez (PROTEUS-DUNES cruises; 2012), the laboratory IFREMER-Marine Geosciences (Plouzané) for the KS-24 core collected in the Bay of Brest (SERABEQ cruises; G. Gregoire PhD thesis, 2016) and the LEMAR laboratory ("Laboratoire des Sciences de l'Environnement Marin"; IUEM, Plouzané) for the A core taken from the Bay of Brest (Défis Golfe de Gascogne cruise; 2003). Main issues of this project are integrated within the theme "Dynamics of Human Settlement and Paleoenvironments » of the Zone Atelier Brest Iroise (ZABrI, INEE-CNRS).

\section{References}

Amat, A. E. 1995. Evolución del paisaje durante los últimos 10000 años en las montañas del Mediterráneo Occidental : ejemplos del Pirineo Oriental y Sierra Nevada. PhD thesis, University of Barcelona. 
Augris, C., Érik, H., Joël, R. 1988. Carte des Sédiments Superficiels et Carte Géologique de La Baie de Douarnenez: Partie Septentrionale. Ifremer.

Augris, C., Ménesguen, A., Hamon, D., Blanchet, A., Le Roy, P., Rolet, J., Jouet, G., Véron, G., Delannoy, H., Drogou, M., Bernard, C., Maillard, X. 2005. Atlas thématique de l'environnement marin de la Baie de Douarnenez. Ifremer (Ed). pp. 61-72.

Ballèvre, M., Bosse, V., Ducassou, C., Pitra, P. 2009. Palaeozoic history of the Armorican Massif: models for the tectonic evolution of the suture zones. Comptes Rendus Geoscience, $341,174-201$.

Ballèvre, M., Bosse, V., Dabard, M.-P., Ducassou, C., Fourcade, S., Paquette, J.-L., Peucat, J.-J., and Pitra, P. 2013. Histoire Géologique Du Massif Armoricain: Actualité de La Recherche. Bulletin de La Société Géologique et Minéralogique de Bretagne 500, 5-96.

Barbier, D., Visset, L. 1997. "Logné, a Peat Bog of European Ecological Interest in the Massif Armorican, Western France: Bog Development, Vegetation and Land-Use History.” Vegetation History and Archaeobotany 6, 69-77.

Beckmann, M. 2004. Pollenanalytische Untersuchung der Zeit der Jäger und-Sammler und der ersten Bauern an zwei Lokalitäten des-Zentralen Schweizer Mittellandes: Umwelt und erste Eingriffe des Menshen in die Vegetation vom Paläolithikum bis zum Jungeneolithikum. Dissertationes Botanicae 390. Berlin: J. Cramer.

Behre, K. E. 1981. The interpretation of anthropogenic indicators in pollen diagrams. Pollen et spores, 23(2), 225-245.

Behre, K.E. 2007. Evidence for Mesolithic agriculture in and around central Europe ? Vegetation History and Archaeobotany 16, 2-3, 203-219. 
870

871 en Bretagne.” Météo France, 85p.

872 Berger, A., Loutre, M. F. 1991. Insolation values for the climate of the last 10 million years.

873 Quaternary Science Reviews, 10(4), 297-317.

874

Beug, H.-J., 1961. Leitfaden der pollenbestimmung. Fisch. Stuttg. 1, 63. 542 pp

875

Beug, H. J. 1965. Pollenanalytische Untersuchungen zur nacheiszeitlichen Geschichte der 876 mediterranen Art im Gardasee-Gebiet. Plant Biology 1, 78, 28-30.

Beug, H.J., 2004. Leitfaden der Pollenbestimmung für Mitteleuropa und angrenzende Gebiete. Verlag Friedrich Pfeil, Munich, 542 p.

879

880

Blanchet, S., Kayser, O., Marchand G., Yven E. 2006. "Le Mésolithique Moyen En Finistère: De Nouvelles Datations Pour Le Groupe de Bertheaume." Bulletin de La Société Préhistorique Française, 507-517.

Blanchet, S., Forré, P., Fromont, N., Hamon, C., Hamon, G. (2010). Un habitat du Néolithique ancien à Betton «Pluvignon» (Ille-et-Vilaine). Présentation synthétique et premiers résultats. Premiers Néolithiques de l’Ouest. Cultures, réseaux, échanges des premières sociétés néolithiques à leur expansion. Presses Universitaires de France, Rennes, $15-40$

Bond, G., Showers, W., Cheseby, M., Lotti, R., Almasi, P., Priore, P., Cullen, H., Hajdas, I., Bonani, G. 1997. “A Pervasive Millennial-Scale Cycle in North Atlantic Holocene and Glacial Climates.” Science, 278, 1257-1266.

Bond, G., Kromer, B., Beer, J., Muscheler, R., Evans, M.N., Showers, W., Hoffmann, S., Lotti-Bond, R., Hajdas, I., and Bonani, G. 2001. "Persistent Solar Influence on North Atlantic Climate during the Holocene.” Science, 294, 2130-2136. 
893 Bonnet, S., Guillocheau, F., Brun, J.-P., Van Den Driessche, J., 2000. Large-scale relief

894

895

896

897

898

899

900

901

902

903

904

905

906

907

908

909

910

911

912

913

914

915

development related to Quaternary tectonic uplift of a Proterozoic-Paleozoic basement: The Armorican Massif, NW France. Journal of Quaternary Research, 105, 19273-19288.

Bradbury, J.P, Dean, W.E., Anderson, R.Y. 1993. "Holocene Climatic and Limnologic History of the North-Central United States as Recorded in the Varved Sediments of Elk Lake, Minnesota: A Synthesis.” Geological Society of America Special Papers, 276, 309-328.

Bramanti, B., Thomas, M. G., Haak, W., Unterländer, M., Jores, P., Tambets, K., AntanaitisJacobs, I., Haidle, M. N., Jankauskas, R., Kind, C. J., Lueth, F., Terberger, T., Hiller, J., Matsumura, S., Forster, P., Burger, J. 2009. Genetic discontinuity between local huntergatherers and central Europe's first farmers. science, 326(5949), 137-140.

Brewer, S., Cheddadi, R., De Beaulieu, J. L., Reille, M. 2002. The spread of deciduous Quercus throughout Europe since the last glacial period. Forest Ecology and Management, $156(1), 27-48$.

Carcaud, N., Cyprien, A. L., Visset, L. 2000. Marais et vallée de la Loire, mémoire des paysages depuis dix mille ans. Étude comparative des marais de Distré et Champtocé et de la vallée de la Loire à Montjean-sur-Loire. Archives d'Anjou, 4, 187-215.

Cassen, S., Audren, C., Hinguant, S., Lannuzel, G., Marchand, G. 1998. L'habitat VilleneuveSaint-Germain du Haut-Mée (Saint-Étienne-en-Coglès, Ille-et-Vilaine). Bulletin de la Société préhistorique française, 41-75.

Chauris, L., Plusquellec, Y., (coord) 1980. Carte Geol. France (1/50 000), feuille Brest (274). Ed. B.R.G.M., Orléans.

Cupillard, C., Magny, M., Richard, H., Ruffaldi, P., Marguier, S. 1994. Mésolithisation et néolithisation d'une zone de moyenne montagne (évolution du peuplement et du paysage de la 
haute vallée du Doubs). Rapport de fin de contrat A.T.P. "Archéologie Métropolitaine », Laboratoire de Chrono-Ecologie, $120 \mathrm{p}$.

David, R. 2014. Modélisation de la végétation holocène du Nord-Ouest de la France: reconstruction de la chronologie et de l'évolution du couvert végétal du Bassin parisien et du Massif armoricain. Thèse de doctorat. Université Rennes 1.

Davis, B.A., Brewer, S., Stevenson, A.C., Guiot, J., 2003. The temperature of Europe during the Holocene reconstructed from pollen data. Quaternary Science Reviews, 22, 1701-1716.

Debenay, J. P., Bicchi, E., Goubert, E., Du Châtelet, E. A. 2006. Spatio-temporal distribution of benthic foraminifera in relation to estuarine dynamics (Vie estuary, Vendée, W France). Estuarine, Coastal and Shelf Science, 67(1), 181-197.

Delaine, M., Armynot du Châtelet, E., Bout-Roumazeilles, V., Goubert, E., Le Cadre, V., Recourt, P., Trentesaux, A., Arthuis, R. 2015. Multiproxy approach for Holocene paleoenvironmental reconstructions from microorganisms (testate amoebae and foraminifera) and sediment analyses: The infilling of the Loire Valley in Nantes (France). The Holocene, 25(3), 407-420.

Delmas, R., Treguer, P., 1983. Evolution saisonnière des nutriments dans un écosystème eutrophe d'Europe occidentale (la rade de Brest). Interactions marines et terrestres. Oceanologica Acta, 6, 345-356.

Deser, C., Alexander, M. A., Xie, S. P., Phillips, A. S. 2010. Sea surface temperature variability: Patterns and mechanisms. Annual review of marine science, 2, 115-143.

Dubouloz, J. 2003. Datation absolue du premier Néolithique du Bassin parisien: complément et relecture des données RRBP et VSG. Bulletin de la Société préhistorique française, 671689. 
939

940

941

942

de Vernal, A., Henry, M., Bilodeau, G., 1999. Techniques de préparation et d'analyse en micropaléontologie. Les Cahiers du GEOTOP, 3, 1-31.

de Vernal, A., Hillaire-Marcel, C., Rochon, A., Fréchette, B., Henry, M., Solignac, S., Bonnet, S. 2013. Dinocyst-based reconstructions of sea ice cover concentration during the Holocene in the Arctic Ocean, the northern North Atlantic Ocean and its adjacent seas. Quaternary Science Reviews, 79, 111-121.

Dodge, J. D., Harland, R. 1991. The distribution of planktonic dinoflagellates and their cysts in the eastern and northeastern Atlantic Ocean. New Phytologist, 118(4), 593-603.

Dréano Y., Giovannacci S., Dupont C., Gruet Y., Hoguin R., Ihuel E., Leroy A., Marchand G., Pailler Y., Sparfel Y., Tresset A. 2007 - Le patrimoine archéologique de l'île Béniguet (Le Conquet, Finistère) - Bilan des recherches 2000-2007, In Quinze ans d'étude et de recherches sur la réserve de Béniguet, Bulletin de la Société des Sciences Naturelles de l'Ouest de la France, nouvelle série, 29, 161-172.

Duplessy, J. C. 1978. Isotope studies. Climatic change, 3, 47-67.

Erny-Rodmann, C., Gross-klee, E., Haas, J. N., Jacomet, S., Zoller, H. 1997. Früher «human impact» und Ackerbau im Übergangsbereich Spätmesolithikum-Frühneolithikum im schweizerischen Mittelland. Jahrbuch der Schweizerischen Gesellschaft für Ur-und Frühgeschichte, 80, 27-56.

Estournès, G., Menier, D., Guillocheau, F., Le Roy, P., Paquet, F., Goubert, E. 2012. The paleo-Etel River incised valley on the Southern Brittany inner shelf (Atlantic coast, France): Preservation of Holocene transgression within the remnant of a middle Pleistocene incision. Marine Geology, 329, 75-92. 
961 Faegri, K., Iversen, J., (Eds.) 1989. Textbook of pollen analysis. 4th Edition by Faegri, K., 962 Kaland, P.E., Krzywinski, K. John Wiley and Sons, Chichester, 328 p.

963 Fatela, F., Taborda, R., 2002. Confidence limits of species proportions in microfossil 964 assemblages. Marine Micropaleontology 45, 169-174.

965 Fernane, A., Gandouin, E., Penaud, A., Van Vliet-Lanoë, B., Goslin, J., Vidal, M., Delacourt, 966 C., 2014. Coastal palaeoenvironmental record of the last 7 kyr BP in NW France: Sub967 millennial climatic and anthropic Holocene signals. The Holocene 24, 1785-1797.

968 Fernane, A., Penaud, A., Gandouin, E., Goslin, J., Van Vliet-Lanoë, B., \& Vidal, M. 2015. 969 Climate variability and storm impacts as major drivers for human coastal marsh withdrawal 970 over the Neolithic period (Southern Brittany, NW France). Palaeogeography, 971 Palaeoclimatology, Palaeoecology, 435, 136-144.

972 Galop, D., Vaquer, J. 2004. Regards croisés sur les premiers indices de l'anthropisation en 973 domaine pyrénéen. Néolithisation précoce. Premières traces d'anthropisation du couvert 974 végétal à partir des données polliniques, 7, 179-194.

975 García-Artola A., Stéphan P., Cearreta A., Kopp R.E., Khan N.S., Horton B.P. 2018. 976 Holocene sea-level database from the Atlantic coast of Europe. Quaternary Science Reviews, $977196,177-192$.

978 Gassin, B., Marchand, G., Claud, É., Guéret, C., Philibert, S. 2013. Les lames à coches du 979 second Mésolithique: des outils dédiés au travail des plantes? Bulletin de la Société 980 préhistorique française, 25-46.

981 Giot, P. R., L'Helgouach, J., Monnier, J. L. 1998. Préhistoire de la Bretagne. Ouest-France. 982588 p. 
983 Gomart, L., Hachem, L., Hamon, C., Giligny, F., Ilett, M. 2015. Household integration in 984 Neolithic villages: A new model for the Linear Pottery Culture in west-central Europe. 985 Journal of Anthropological archaeology, 40, 230-249.

986 Gooday, A. J. 2003. Benthic foraminifera (Protista) as tools in deep-water 987 palaeoceanography: environmental influences on faunal characteristics. Advances in marine 988 biology, 46, 1-90.

989 Goslin, J., Vliet-Lanoë, B. V., Stéphan, P., Delacourt, C., Fernane, A., Gandouin, E., Hénaff, 990 A., Penaud, A., Suanez, S. 2013. Holocene relative sea-level changes in western Brittany 991 (France) between 7600 and 4000 cal. BP: Reconstitution from basal-peat deposits. 992 Géomorphologie: relief, processus, environnement, 19(4), 425-444.

993 994 995

996 997 998 999

Goslin, J., 2014. L'évolution du niveau marin relatif le long des côtes du Finistère (Bretagne, France) de 8000 BP à l'actuel: entre dynamiques régionales et réponses locales. $\mathrm{PhD}$ Thesis, IUEM, Brest University, 14 February 2014, pp. 355.

Goslin, J., van Vliet Lanoë, B., Spada, G., Bradley, S., Tarasov, L., Neill, S., Suanez, S., 2015. A new Holocene relative sea-level curve for western Brittany (France): Insights on isostatic dynamics along the Atlantic coasts of north-western Europe. Quaternary Science Reviews, 129, 341-365.

Gouletquer, P., Kayser, O., Le Goffic, M., \& Marchand, G. 1994. Approche géographique du Mésolithique de la Bretagne. Le Tardiglaciaire en Europe du nordouest, Actes du 119e congrès national des Sociétés historiques et scientifiques, Amiens, 279-292.

Gouletquer, P., Kayser, O., Le Goffic, M., Léopold, P., Marchand, G., \& Moullec, J. M. 1996. Où sont passés les Mésolithiques côtiers bretons? Bilan 1985-1995 des prospections de surface dans le Finistère. Revue archéologique de l'Ouest, 13(1), 5-30. 
Gregoire, G., Ehrhold, A., Le Roy, P., Jouet, G., Garlan, T., 2016. Modern morphosedimentological patterns in a tide-dominated estuary system: the Bay of Brest (west Britanny, France). Journal of Maps, 12, 1152-1159.

Gregoire, G., Le Roy, P., Ehrhold, A., Jouet, G., Garlan, T. 2017. Control factors of Holocene sedimentary infilling in a semi-closed tidal estuarine-like system: the bay of Brest (France). Marine Geology, 385, 84-100.

Guenet, P. 1995. Analyse palynologique du sondage du Petit Castelou. In J. Guilaine (dir.), Temps et espace dans le bassin de l'Aude du Néolithique à l'Age du Fer. Centre d'Anthropologie, Toulouse, 334-340.

Guéret, C. 2013. Character and variability of Early Mesolithic toolkits in Belgium and Northern France: the contribution of a functional approach. In «Palethnographie du Mésolithique: recherches sur les habitats de plein air entre Loire et Neckar/Mesolithic Palethnography ». Actes de la table ronde internationale de Paris. Société préhistorique française Paris, 147-167.

Guéret, C., Gassin, B., Jacquier, J., Marchand, G. 2014. Traces of plant working in the Mesolithic shell midden of Beg-an-Dorchenn (Plomeur, France). Mesolithic Miscellany, 22(3), 3-15.

Guilcher, A. 1948. Le relief de la Bretagne méridionale de la baie de Douarnenez à la Vilaine. PhD. Thèse Paris, H . Potier (éd.), La Roche-sur-Yon, 682 p.

Haak, W., Balanovsky, O., Sanchez, J. J., Koshel, S., Zaporozhchenko, V., Adler, C. J., Der Sarkissian, C.S.I., Brandt, G., Scharwtz, C., Nicklisch, N., Dresely, V., Fritsch, B., Balanovska, E. 2010. Ancient DNA from European early neolithic farmers reveals their near eastern affinities. PLoS biology, 8(11), e1000536. 
Hallegouët, B. 1989. La presqu'île de Crozon: évolution géomorphologique. HistorienGéographe, 318, 141-148.

Hallegouët B., Lozac'h G., Vigouroux F. 1994. Formation de la Rade de Brest. In Corlay, J.$P$., (coord.) Atlas permanent de la Mer et du Littoral $\mathrm{n}^{\circ} 1$. Université de Nantes. CNRS-URA904/EDITMAR. p. 21.

Hammarlund, D., Björck, S., Buchardt, B., \& Thomsen, C. T. 2005. Limnic responses to increased effective humidity during the 8200 cal. yr BP cooling event in southern Sweden. Journal of Paleolimnology, 34(4), 471-480.

Hamon, G. 2008. Productions céramiques du Néolithique armoricain. Bulletin-Société d'archéologie et d'histoire du Pays de Lorient, 37, 21-32.

Hinschberger, F., Pauvret, R. B. 1968. Les fonds sous-marins de l'Iroise et de la Baie de Douarnenez (Finistère). Reconstitution d'un réseau hydrographique immergé. Norois, 58(1), 213-225.

Huntley, B. 1993. Rapid early-Holocene migration and high abundance of hazel (Corylus avellana L.): alternative hypotheses. In Climate change and human impact on the landscape. Springer Netherlands, 205-215.

Jalut, G., Vernet, J. L. 1989. La végétation du Pays de Sault et de ses marges depuis 15000 ans: réinterprétation des données palynologiques et apports de l'anthracologie. Pays de Sault, espaces, peuplement, populations. CNRS, Toulouse, 23-41.

Jiang, H., Muscheler, R., Björck, S., Seidenkrantz, M. S., Olsen, J., Sha, L., Sjolte, J., Eiriksson, J., Ran, L., Knudsen, K.L, Knudsen, M. F. 2015. Solar forcing of Holocene summer sea-surface temperatures in the northern North Atlantic. Geology, 43(3), 203-206. 
1051

1052

1053

1054

1055

1056

1057

1058

1059

1060

1061

1062

1063

1064

1065

1066

1067

1068

1069

1070

1071

Joly, C., Visset, L. 2005. Nouveaux éléments d'anthropisation sur le littoral vendéen dès la fin du Mésolithique. Comptes Rendus Palevol, 4(3), 285-293.

Joly, C., Barillé, L., Barreau, M., Mancheron, A., Visset, L., 2007. Grain and annulus diameter as criteria for distinguishing pollen grains of cereals from wild grasses. Rev. Palaeobot. Palynol. 146, 221-233.

Joly, C., Visset, L. 2009. Evolution of vegetation landscapes since the Late Mesolithic on the French West Atlantic coast. Review of Palaeobotany and Palynology, 154(1), 124-179.

Jorissen, F.J., Fontanier, C., Thomas, E. 2007. Chapter seven paleoceanographical proxies based on deep-sea benthic foraminiferal assemblage characteristics. Developments in Marine Geology, 1, 263-325.

Jouet, G., Augris, C., Hallegouët, B., Le Roy, P., Rolet, J. 2003. La vallee d'Ys: un paleoreseau hydrographique immerge en baie de Douarnenez (Finistere, France). Comptes Rendus Geoscience, 335(5), 487-494.

Kirleis, W., Klooß, S., Kroll, H., Müller, J. 2012. Crop growing and gathering in the northern German Neolithic: a review supplemented by new results. Vegetation history and archaeobotany, 21(3), 221-242.

Knight, J.R., Folland, C.K., Scaife, A.A., 2006. Climate impacts of the Atlantic multidecadal oscillation. Geophysical Research Letters, 33(17).

Lambert, C., Vidal, M., Penaud, A., Combourieu-Nebout, N., Lebreton, V., Ragueneau, O., Gregoire, G., 2017. Modern palynological record in the Bay of Brest (NW France): signal calibration for palaeo-reconstructions. Review of Palaeobotany and Palynology 244, 13-25. 
1072

1073

1074

1075

1076

1077

1078

1079

1080

1081

1082

1083

1084

1085

1086

1087

1088

1089

1090

1091

1092

1093

1094

Lambert, C., Penaud, A., Vidal, M., Klouch, K., Gregoire, G., Ehrhold, A., Eynaud, F., Schmidt, S., Ragueneau, O., Siano, R. 2018. Human-induced river runoff overlapping natural climate variability over the last 150 years: Palynological evidence (Bay of Brest, NW France). Global and Planetary Change, 160, 109-122.

Lefort, J. P. 1973. La "zonale” Biscaye-Labrador: mise en évidence de cisaillements dextres antérieurs à l'ouverture de l'Atlantique Nord. Marine Geology, 14(5), 33-38.

Legigan, P., Marambat, L. 1993. Âge de la formation d'une lagune landaise : premières données palynologiques et radiométriques. Bull. Soc. De Bordeaux, 118, 432, 433-443.

Le Roy, P., Jouet, G., 2005. Remplissage sédimentaire meuble. In : Augris, C., Ménesguen, A., Hamon, D., Blanchet, A., Le Roy, P., Rolet, J., Jouet, G., Véron, G., Delannoy, H., Drogou, M., Bernard, C., Maillard, X., 2005. Atlas thématique de l'environnement marin de la Baie de Douarnenez. Ifremer (Ed), 61-72.

Leroyer, C., Mordant, D., Lanchon, Y. 2004. L'anthropisation du Bassin parisien du VIIe au IVe millénaire d'après les analyses polliniques de fonds de vallées: mise en évidence d'activités agro-pastorales très précoces. Néolithisation précoce. Première trace d'anthropisation du couvert végétal à partir des données polliniques, 11-27.

Leroyer, C., Allenet, G. 2006. L'anthropisation du paysage végétal d'après les données polliniques: l'exemple des fonds de vallées du Bassin parisien. L'érosion entre Société, Climat et Paléoenvironnement. Actes de la Table Ronde en l'honneur de René NeboitGuilhot. Coll.«Nature et Société, 3, 63-72.

Lotter, A. F. 1999. Late-glacial and Holocene vegetation history and dynamics as shown by pollen and plant macrofossil analyses in annually laminated sediments from Soppensee, central Switzerland. Vegetation History and Archaeobotany, 8(3), 165-184. 
1095

1096

1097

1098

1099

1100

1101

1102

1103

1104

1105

1106

1107

1108

1109

1110

1111

1112

1113

1114

1115

Mangerud, J., Bondevik, S., Gulliksen, S., Hufthammer, A. K., Høisæter, T. 2006. Marine 14

C reservoir ages for 19th century whales and molluscs from the North Atlantic. Quaternary Science Reviews, 25(23), 3228-3245.

Marchand, G. 2005. Le Mésolithique final en Bretagne: une combinaison des faits archéologiques. Mémoires de la Société préhistorique française, 36, 67-86.

Marchand, G., Pailler, Y., Tournay, G. 2006. Carrément à l'Ouest! Indices du VilleneuveSaint-Germain au centre de la Bretagne (le Dillien à Cléguérec et Bellevue à Neulliac; Morbihan). Bulletin de la Société préhistorique française, 519-533.

Marchand, G. 2007. Neolithic fragrances: Mesolithic-Neolithic interactions in western France. In Proceedings-British Academy (Vol. 144, p. 225). Oxford University Press Inc.

Marchand, G. 2014. Préhistoire atlantique: Fonctionnement et évolution des sociétés du Paléolithique au Néolithique. Ed. Errance. 519 p.

Marcigny, C., Ghesquiere, E., Juhel, L., Charraud, F. 2010. Entre Néolithique ancien et Néolithique moyen en Normandie et dans les îles anglo-normandes. Parcours chronologique. Premiers Néolithiques de l'Ouest. Cultures, réseaux, échanges des premières sociétés néolithiques à leur expansion, 117-62.

Marguerie, D. 1991. Confrontation des données polliniques et anthracologiques (Défrichement du milieu forestier et développement de la lande régressive à partir du Néolithique en Armorique). Revue d'Archéométrie, 15(1), 75-82.

Marret, F., Zonneveld, K. A. 2003. Atlas of modern organic-walled dinoflagellate cyst distribution. Review of Palaeobotany and Palynology, 125(1), 1-200. 
Mayewski, P. A., Meeker, L. D., Twickler, M. S., Whitlow, S., Yang, Q., Lyons, W. B., \& Prentice, M. 1997. Major features and forcing of high-latitude northern hemisphere atmospheric circulation using a 110,000-year-long glaciochemical series. Journal of Geophysical Research: Oceans, 102(C12), 26345-26366.

Mayewski, P. A., Rohling, E. E., Stager, J. C., Karlén, W., Maasch, K. A., Meeker, L. D., Meyerson, E.A., Gasse, F., van Kreveld, S., Holmgren, K., Lee-Thorpe, J., Rosqvist, G., Rack, F., Staubwasser, M., Schneider, R.R., Steig, E.J. 2004. Holocene climate variability. Quaternary research, 62(3), 243-255.

McCarthy, G.D., Haigh, I.D., Hirschi, J.J.-M., Grist, J.P., Smeed, D.A., 2015. Ocean impact on decadal Atlantic climate variability revealed by sea-level observations. Nature 521, 508 510.

McClatchie, M., Bogaard, A., Colledge, S., Whitehouse, N. J., Schulting, R. J., Barratt, P., McLaughlin, T. R. 2014. Neolithic farming in north-western Europe: archaeobotanical evidence from Ireland. Journal of Archaeological Science, 51, 206-215.

Meeker, L. D., Mayewski, P. A. 2002. A 1400-year high-resolution record of atmospheric circulation over the North Atlantic and Asia. The Holocene, 12(3), 257-266.

Mélou, M., Plusquellec, Y. 1974. “Carte Géologique de La France a1/50000, Feuille de Douarnenez, No. 309.” BRGM, Brest.

Mertens, K.N., Verhoeven, K., Verleye, T., Louwye, S., Amorim, A., Ribeiro, S., Deaf, A.S., Harding, I.C., De Schepper, S., González, C., Kodrans-Nsiah, M., De Vernal, A., Henry, M., Radi, T., Dybkjaer, K., Poulsen, N.E., Feist-Burkhardt, S., Chitolie, J., Heilmann-Clausen, C., Londeix, L., Turon, J-L., Marret, F., Matthiessen, J., McCarthy, F.M.G., Prasad, V., Pospelova, V., Kyffin Hughes, J.E., Riding, J.B., Rochon, A., Sangiorgi, F., Welters, N., 
Sinclair, N., Thun, C., Soliman, A., Van Nieuwenhove, N., Vink, A., Young, M. 2009. Determining the absolute abundance of dinoflagellate cysts in recent marine sediments: the Lycopodium marker-grain method put to the test. Rev. Palaeobot. Palynol. 157, 238-252.

Mojtahid, M., Jorissen, F. J., Garcia, J., Schiebel, R., Michel, E., Eynaud, F., Gillet, H., Cremer, M., Diz Ferreiro, P., Siccha, M., Howa, H. 2013. High resolution Holocene record in the southeastern Bay of Biscay: Global versus regional climate signals. Palaeogeography, Palaeoclimatology, Palaeoecology, 377, 28-44.

Monbet, Y., Bassoulet, P., 1989. Bilan des connaissances océanographiques en rade de Brest. Rapport CEA/IPSN, code DERO/EL 89-23. IFREMER-DEL-BP 70-29280 Plouzane, France, $106 \mathrm{pp}$.

Moore, P.D., Webb, J.A., Collinson, M.E., 1991. Pollen analysis. $2^{\text {nd }}$ Edition. Blackwell Scientific Publications, Oxford, 216 pp.

Morzadec-Kerfourn, M. T. 1974. Variations de la ligne de rivage armoricaine au Quaternaire: analyses polliniques de dépôts organiques littoraux. $\mathrm{PhD}$, Université de Rennes, Institut de géologie.

Morzadec-Kerfourn, M.T., 1976. La signification écologique des dinoflagellés et leur intérêt pour l'étude des variations du niveau marin. Rev. Micropaléontologie 18, 229-235.

Morzadec-Kerfourn, M.-T., 1977. Les kystes de dinoflagellés dans les sédiments récents le long des côtes Bretonnes. Revue de Micropaleontologie, 20, 157-166.

Morzadec-Kerfourn, M.T., 1979. Les kystes de Dinoflagellés. Géologie Méditerranéenne 6, $221-246$. 
Mudie, P.J., Harland, R., Matthiessen, J., \& de Vernal, A. 2001. Marine dinoflagellate cysts and high latitude Quaternary paleoenvironmental reconstructions: an introduction. Journal of Quaternary Science, 16(7), 595-602.

Musset, R. 1934. La formation du réseau hydrographique de la Bretagne occidentale. Annales de Géographie. Colin A. (Ed.), 43, 246, 561-578

Naughton, F., Bourillet, J. F., Sánchez Goñi, M. F., Turon, J. L., Jouanneau, J. M. 2007. Long-term and millennial-scale climate variability in northwestern France during the last 8850 years. The Holocene, 17(7), 939-953.

Nesje, A., Matthews, J. A., Dahl, S. O., Berrisford, M. S., Andersson, C. 2001. Holocene glacier fluctuations of Flatebreen and winter-precipitation changes in the Jostedalsbreen region, western Norway, based on glaciolacustrine sediment records. The Holocene, 11(3), 267-280.

Nielsen, A. B. 2003. Pollen Based Quantitative Estimation of Land Cover: Relationships Between Pollen Sedimentation in Lakes and Land Cover as Seen on Historical Maps in Denmark AD 1800: PhD, GEUS, Geological Survey of Denmark and Greenland.

O’Brien, S.R., Mayewski, P.A., Meeker, L.D., Meese, D.A., Twickler, M.S., \& Whitlow, S.I. 1995. Complexity of Holocene climate as reconstructed from a Greenland ice core. Science, 270(5244), 1962-1964.

Ouguerram, A., Visset, L. 2001. Paysages et interactions homme/milieu dans la moyenne vallée de l'Erdre du Néolithique aux Époques actuelles: Étude pollinique des marais de Lisle. Annales de Bretagne et des pays de l'Ouest. Université de Haute-Bretagne, 108(1), 129-146.

Pailler, Y., Stéphan, P., Gandois, H., Nicolas, C., Sparfel, Y., Tresset, A., Donnart, K., Fichaut, B., Suanez, S., Dupont, C., Le Clézio, L., Marcoux, N., Pineau, A., Salanova, L., 
Sellami, F., Debue, K., Josselin, J., Dietxch-Sellami, M.F. 2011. Évolution des paysages et occupation humaine en mer d'Iroise (Finistère, Bretagne) du Néolithique à l'Âge du Bronze. Norois. Environnement, aménagement, société, (220), 39-68.

Pailler, Y., Stéphan, P., Gandois, H., Nicolas, C., Sparfel, Y., Tresset, A., Donnart, K., Dréano, Y., Fichaut, B., Suanez, S., Dupont, C., Audouard, L., Marcoux, N., Mougne, C., Salanova, L., Sellami, F., Dietsch-Sellami, M.-F. 2014. Landscape evolution and human settlement in the Iroise Sea (Brittany, France) during the Neolithic and Bronze Age. Proceedings of the Prehistoric Society (80), 105-139. Cambridge University Press.

Perez-Belmonte, L. 2008. Caractérisation environnementale, morphosédimentaire et stratigraphique du Golfe du Morbihan pendant l'Holocène terminal: Implications évolutives. $\mathrm{PhD}$, Université de Bretagne Sud.

Puertas, O. 1999. Premiers indices polliniques de néolithisation dans la plaine littorale de Montpellier (Hérault, France). Bulletin de la Société préhistorique française, 15-20.

Redois, F. 1996. Les foraminifères benthiques actuels bioindicateurs du milieu marin exemples du plateau continental sénégalais et de l'estran du golfe du Morbihan (France). PhD, Université d'Angers.

Reille, M., 1995. Pollen et spores d'Europe et d'Afrique du Nord: supplement 1. Laboratoire de Botanique Historique et Palynologie, Marseille, 327 pp.

Reimer, P. J., Bard, E., Bayliss, A., Beck, J. W., Blackwell, P. G., Ramsey, C. B., Buck, C.E., Cheng, H., Edwards, R.L., Friedrich, M., Grootes, P.M., Guilderson, T.P., Haflidason, H., Hajdas, I., Hatté, C., Heaton, T.J., Hoffmann, D.L., Hogg, A.G., Hughen, K.A., Kaiser, K.F., Kromer, B., Manning, S.W., Niu, M., Reimer, R.W., Richards, D.A., Scott, E.M., Southon, 
J.R., Staff, R.A., Turney, C.S.M., van der Plicht, J.. 2013. IntCal13 and Marine13 radiocarbon age calibration curves 0-50,000 years cal BP. Radiocarbon, 55(4), 1869-1887.

Rochon, A., de Vernal, A. 1994. Palynomorph distribution in recent sediments from the Labrador Sea. Canadian Journal of Earth Sciences, 31(1), 115-127.

Rochon, A., de Vernal, A. de, Turon, J.-L., Matthiessen, J., Head, M.J., 1999. Distribution of recent dinoflagellate cysts in surface sediments from the North Atlantic Ocean and adjacent seas in relation to sea-surface parameters. Am. Assoc. Stratigr. Palynol. Contrib. Ser. 35, 1146.

Rossi, V., Horton, B. P., Corbett, D. R., Leorri, E., Perez-Belmonte, L., Douglas, B. C. 2011. The application of foraminifera to reconstruct the rate of 20th century sea level rise, Morbihan Golfe, Brittany, France. Quaternary Research, 75(1), 24-35.

Ruddiman, W. F., McIntyre, A. 1981. The North Atlantic Ocean during the last deglaciation. Palaeogeography, Palaeoclimatology, Palaeoecology, 35, 145-214.

Ruffaldi, P. 1999. Premières traces polliniques de néolithisation des zones de basse altitude de Lorraine (France) [First pollen evidences of an neolithic presence in low altitude areas, Lorraine (France)]. Quaternaire, 10(4), 263-270.

Ruprich-Robert, Y., Cassou, C., 2015. Combined influences of seasonal East Atlantic Pattern and North Atlantic Oscillation to excite Atlantic multidecadal variability in a climate model. Climate Dynamics, 44(1-2), 229-253.

Sampietro, M. L., Lao, O., Caramelli, D., Lari, M., Pou, R., Marti, M., Bertranpetit, J., Lalueza-Fox, C. 2007. Palaeogenetic evidence supports a dual model of Neolithic spreading into Europe. Proceedings of the Royal Society of London B: Biological Sciences, 274(1622), 2161-2167. 
Schulting, R. J., Richards, M. P. 2001. Dating women and becoming farmers: new palaeodietary and AMS dating evidence from the Breton Mesolithic cemeteries of Téviec and Hoëdic. Journal of Anthropological Archaeology, 20(3), 314-344.

Skoglund, P., Malmström, H., Raghavan, M., Storå, J., Hall, P., Willerslev, E., Gilbert, M.T.P., Götherström, A., Jakobsson, M. 2012. Origins and genetic legacy of Neolithic farmers and hunter-gatherers in Europe. Science, 336(6080), 466-469.

Steinhilber, F., Beer, J., Fröhlich, C. 2009. Total solar irradiance during the Holocene. Geophysical Research Letters, 36(19).

Stéphan, P. 2008. Les flèches de galets de Bretagne: morphodynamiques passée, présente et prévisible. Thèse de Doctorat. Université de Bretagne Occidentale.

Stéphan, P., Goslin, J. 2014. Évolution du niveau marin relatif à l'Holocène le long des côtes françaises de l'Atlantique et de la Manche: réactualisation des données par la méthode des «sea-level index points». Quaternaire: Revue de l'Association française pour l'étude du Quaternaire, 25(4), 295-312.

Stéphan, P., Goslin, J., Pailler, Y., Manceau, R., Suanez, S., Vliet-Lanoë, V., Hénaff, A., Delacourt, C. 2015. Holocene salt-marsh sedimentary infilling and relative sea-level changes in West Brittany (France) using foraminifera-based transfer functions. Boreas, 44(1), 153177.

Stuiver, M., Reimer, P. J. 1993. Extended 14C data base and revised CALIB 3.0 14C age calibration program. Radiocarbon, 35(1), 215-230.

Tinevez, J. Y., Hamon, N., Querré, G., Marchand, G., Pailler, Y., Darboux, J. R., Donnart, K., Marcoux, N., Pustoc'h, F., Quesnel, L., Oberlin, C. 2015. Les vestiges d'habitat du 
1251 Néolithique ancien de Quimper, Kervouyec (Finistère). Bulletin de la Société préhistorique 1252 française, 112(2), 269-316.

1253 Tinner, W., Hubschmid, P., Wehrli, M., Ammann, B., Conedera, M. 1999. Long-term forest 1254 fire ecology and dynamics in southern Switzerland. Journal of Ecology, 87(2), 273-289.

1255 Tinner, W., Lotter, A. F. 2001. Central European vegetation response to abrupt climate 1256 change at $8.2 \mathrm{ka}$. Geology, 29(6), 551-554.

1257 Tinner, W., Nielsen, E. H., Lotter, A. F. 2007. Mesolithic agriculture in Switzerland? A 1258 critical review of the evidence. Quaternary Science Reviews, 26(9-10), 1416-1431.

1259 Tréguer, P., Goberville, E., Barrier, N., L’Helguen, S., Morin, P., Bozec, Y., Rimmelin1260 Maury, P., Czamanski, M., Grossteffan, E., Cariou, T., Répécaud, M., Quéméner, L. 2014. 1261 Large and local-scale influences on physical and chemical characteristics of coastal waters of 1262 Western Europe during winter. Journal of Marine Systems, 139, 79-90.

1263 Triat-Laval, H. 1978: Contribution pollenanalytique à l'histoire tardi-et postglaciaire de la 1264 végétation de la basse vallée du Rhône. Thèse de doctorat de l'Universite d'Aix-Marseille III, $1265343 \mathrm{pp}$.

Troadec, P., Le Goff, R., 1997. Etat des lieux et des milieux de la rade de Brest et de son bassin versant. Phase Préliminaire du Contrat Baie Rade Brest. Edition Communauté Urbaine de Brest, 335 pp.

Visset, L. 1979. Recherches palynologiques sur la vegetation pleistocene et holocene de quelques sites du district phytogeographique de basse-loire. PhD, Université de Nantes.

Visset, L., L'Helgouac'h, J., Bernard, J. 1996. La tourbière submergée de la pointe de 1272 Kerpenhir à Locmariaquer (Morbihan). Etude environnementale et mise en évidence de 
1273 déforestations et de pratiques agricoles néolithiques. Revue archéologique de l'Ouest, 13(1), 79-87.

1275 Visset, L., Hauray, G., Charrieau, L., Rouzeau, N. 2001. Paléoenvironnement urbain: histoire 1276 du comblement des vallées de la métropole nantaise, du Tardiglaciaire à la fin de l'Holocène. 1277 In Annales de Bretagne et des pays de l'Ouest, Université de Haute-Bretagne, 108(1), 1471278165.

1279 Visset, L., Cyprien, A. L., Carcaud, N., Ouguerram, A., Barbier, D., Bernard, J. 2002. Les 1280 prémices d'une agriculture diversifiée à la fin du Mésolithique dans le Val de Loire (Loire armoricaine, France). Comptes Rendus Palevol, 1(1), 51-58.

Visset, L., Bernard, J. 2006. Evolution du littoral et du paysage, de la presqu'île de Rhuys à la rivière d'Etel (Massif armoricain-France), du Néolithique au Moyen Âge. ArchéoSciences. Revue d'archéométrie, (30), 143-156.

von Cramon-Taubadel, N., Pinhasi, R. 2011. Craniometric data support a mosaic model of demic and cultural Neolithic diffusion to outlying regions of Europe. Proceedings of the Royal Society of London B: Biological Sciences. Holocene cold events. Quaternary Science Reviews, 30(21), 3109-3123.

Willcox, G. 2005. The distribution, natural habitats and availability of wild cereals in relation to their domestication in the Near East: multiple events, multiple centres. Vegetation History 1292 and Archaeobotany, 14(4), 534-541.

1293 Ziegler, P.A., 1992. European Cenozoic rift system. Tectonophysics 208, 91-111. 
Zonneveld, K.A., Marret, F., Versteegh, G.J., Bogus, K., Bonnet, S., Bouimetarhan, I., Crouch, E., de Vernal, A., Elshanawany, R., Edwards, L., Esper, O., Forke, S., Grosfeld, K., Henry, M., Holzwarth, U., Kielt, J-F., Kim, S-Y., Ladouceur, S., Ledu, D., Chen, L., Limoges, A., Londeix, L., Lu, S-H., Mahmoud, M.S., Marino, G., Matouka, K., Matthiessen, J., Mildenhal, D.C., Mudie, P., Neil, H.L., Pospelova, V., Qi, Y., Radi, T., Richerol, T., Rochon, A., Sangiorgi, F., Solignac, S., Turon, J-L., Verleye, T., Wang, Y., Wang, Z., Young, M. 2013. Atlas of modern dinoflagellate cyst distribution based on 2405 data points. Rev. Palaeobot. Palynol. 191, 1-197.

\section{Figure caption}

Figure 1: a) Location of study sites in North Western France; location of sediment cores on the bathymetric maps of the (b) Bay of Douarnenez (black star) and of the (c) Bay of Brest (white stars).

Figure 2: Schematic scenario of the Bay of Douarnenez sediment infilling (after Le Roy and Jouet, 2005). Four sketches related to the sedimentary units defined from seismic and sedimentological analyses (cf details in Le Roy and Jouet, 2005).

Figure 3: a) Pictures and b) XR radiography of the VC-08 core. The red strips represent the sampled core portion to perform palynological analyzes.

Figure 4: Sedimentological log of the VC-08 core (b), grain size evolution and magnetic susceptibility along the core (a). For the different sedimentary units (identified by color strips), a graph representing the grain percentages distribution by size was added. ${ }^{14} \mathrm{C}$ dates are represented by red stars on the log. 
Figure 5: Cores of the Bay of Brest, "A" and KS-24, and their location on a MNT of the Bay of Roscanvel with their bathymetric position (c). Sedimentological logs, photographs and Xray radiography for the "A" (a) and KS-24 cores (b). The ${ }^{14} \mathrm{C}$ dates are represented on the logs by red stars. The red strips represent the sampled core portion to perform palynological analyzes.

Figure 6: a) VC-08 (Bay of Douarnenez) and b) "A" core (Bay of Brest) age models with their sedimentological logs., linear regression lines (in black) and sedimentation rates in $\mathrm{cm} / \mathrm{yr}$.

Figure 7: Graphs against depths with major taxa (greater than 2\%) of dinocysts (a) and pollen (b) along the VC-08 core, Bay of Douarnenez. The ${ }^{14} \mathrm{C}$ dates are represented by red stars. The dotted lines represent the pollen concentration peaks.

Figure 8: Diagram depicted in ages, from the VC-08 core, grouping together data from palynological counting (Pollen, dinocyst and spore concentrations, percentages of trees, Corylus, Quercus, Poaceae, Brassicaceae, Rumex, Cerealia, the dinocyst L.machaerophorum and the total Pollen / dinocysts ratio), and the magnetic susceptibility, with respect to sedimentary units defined in Figure 4.

Figure 9: Diagram in depth grouping the major taxa (greater than 2\%) of dinocysts (a) and pollen (b) for the "A" and KS-24 cores, both taken from the Bay of Roscanvel and plotted one above the other according to the time periods covered by the two sequences. The ${ }^{14} \mathrm{C}$ dates are represented by red stars. For the "A" core, the most significant minor pollen taxa (greater than $1 \%)$ were also reported. The dotted lines represent the pollen concentration peaks.

Figure 10: Major benthic foraminiferal taxa data plotted against depths (greater than $2 \%$ ) in the "A" and KS-24 cores. ${ }^{14} \mathrm{C}$ dates are represented by red stars. Ammonia spp, Cibicides spp, P. mediterranensis, Epiphytic species, Lagena spp and Miliolideae are represented in percentages according to a main sum excluding the Elphidium species, major taxa that greatly 
tainted the individual signal of each one. The isotopic data measured on shells of $E$. aculeatum species are added to the graph.

Figure 11: Mean palynological (pollen and dinocysts) and micropalaeontological (benthic foraminifera) data for the "A" and KS-24 cores represented in pie charts (a). Diagrams representing two models of the landscape evolution in the Bay of Roscanvel following the sea level rise (b). On each model, the typical foraminifera encountered in the different environments according to their ecology were added.

Figure 12: a) Published reconstituted palaeoclimatic data across the Holocene in the North Atlantic region (solar irradiance (dTSi) by Steinhilder et al. 2009, Sea surface temperature (SST) by Jiang et al., 2015 and Northern Hemisphere summer insolation by Berger and Loutre, 1991) and the detrital Hematite Stained Grains by Bond et al., 2008. b) Diagram showing the palynological data of the "A" core between 6,600 and 5,400 years Cal. BP. (from left to right: pollen and dinocyst concentrations, tree percentages, Corylus, Alnus, percentages and the L. machaerophorum / S. bentorii ratio). c) Diagram showing the palynological data of the VC-08 core between 8,700 and 8,400 years Cal. BP with the same succession of palynological proxies. The temporal extent of each core is represented by a black rectangle in the a) part and the temporal extent of the graphs b) and c) is represented by a blue rectangle. The limits of palynozones A-B / A-C and VC-B / VC-C have also been reported in the a) part of the figure.

Figure 13: Pollen grains photographs of wild Poaceae (a) and cereals (b), with grain and annulus diameter measurements for each one, on 4 levels of the VC-08 core.

Figure 14: Diagram in depth from the VC-08 core, representing variations of some herbaceous taxa percentages (i.e. Cerealia-type, other Poaceae, Brassicaceae, Rumex sp.) and the occurrences of Plantago lanceolata. 
1365 Figure 15: Map showing the first occurrences of Cerealia in published pollen records, with 1366 related dates. The two circled areas (Teviecien and Retzien) delimit the cultural specificities 1367 of the end of the Mesolithic after Marchand (2005). The gray arrows correspond to the 1368 different neolithisation paths reaching Western Europe. 


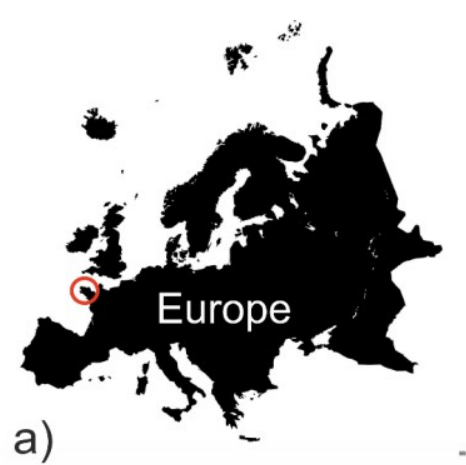

a)


KS-24 core

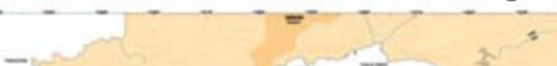

$\left(\frac{\sqrt{7}}{7}{ }^{N}\right.$

Atlantic

Ocean

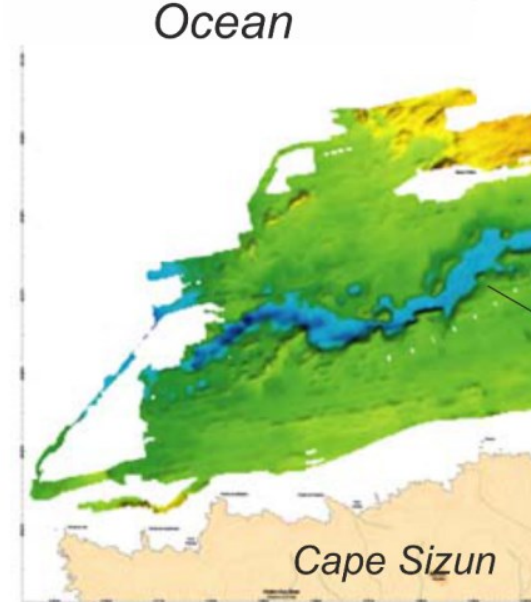

b)

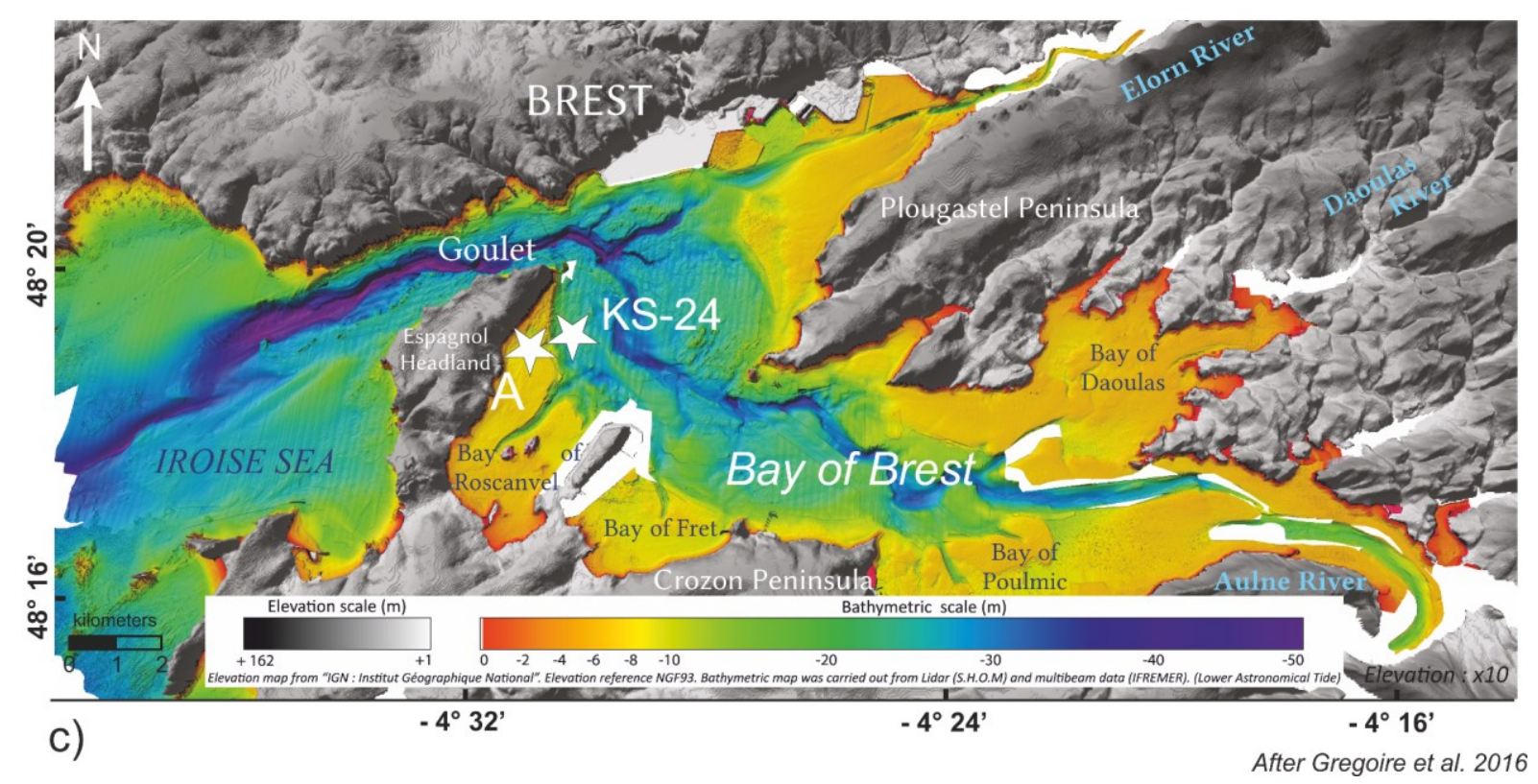

Figure 1 


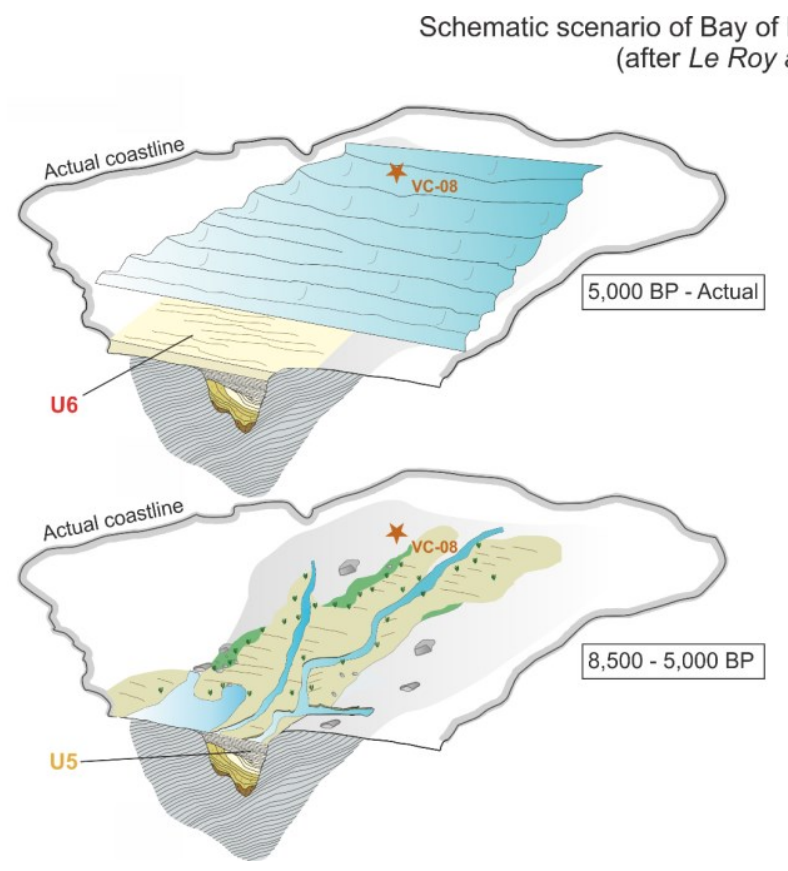

sedimentary infilling (after Le Roy and Jouet, 2005)

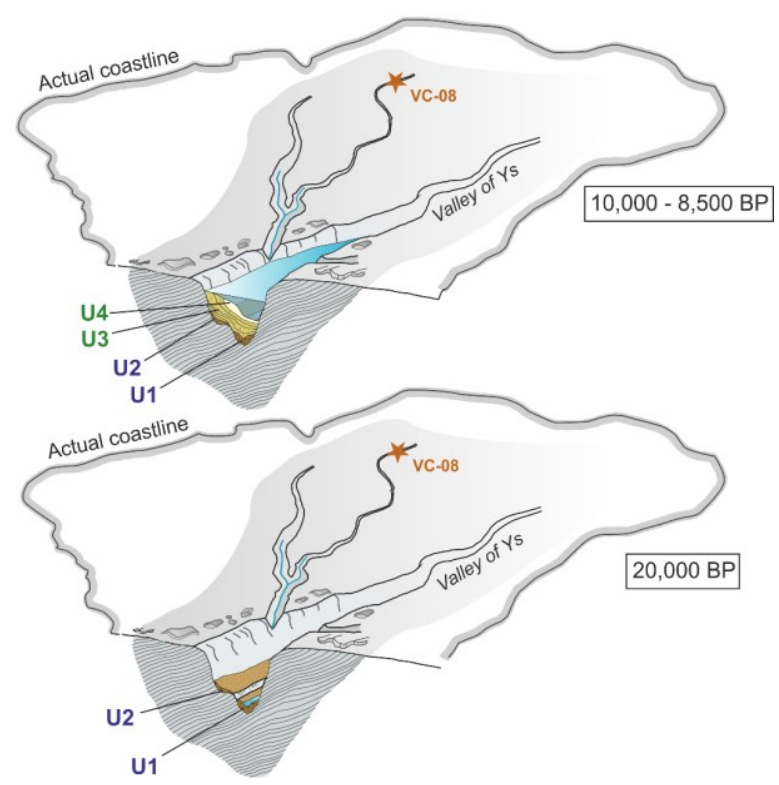

Figure 2
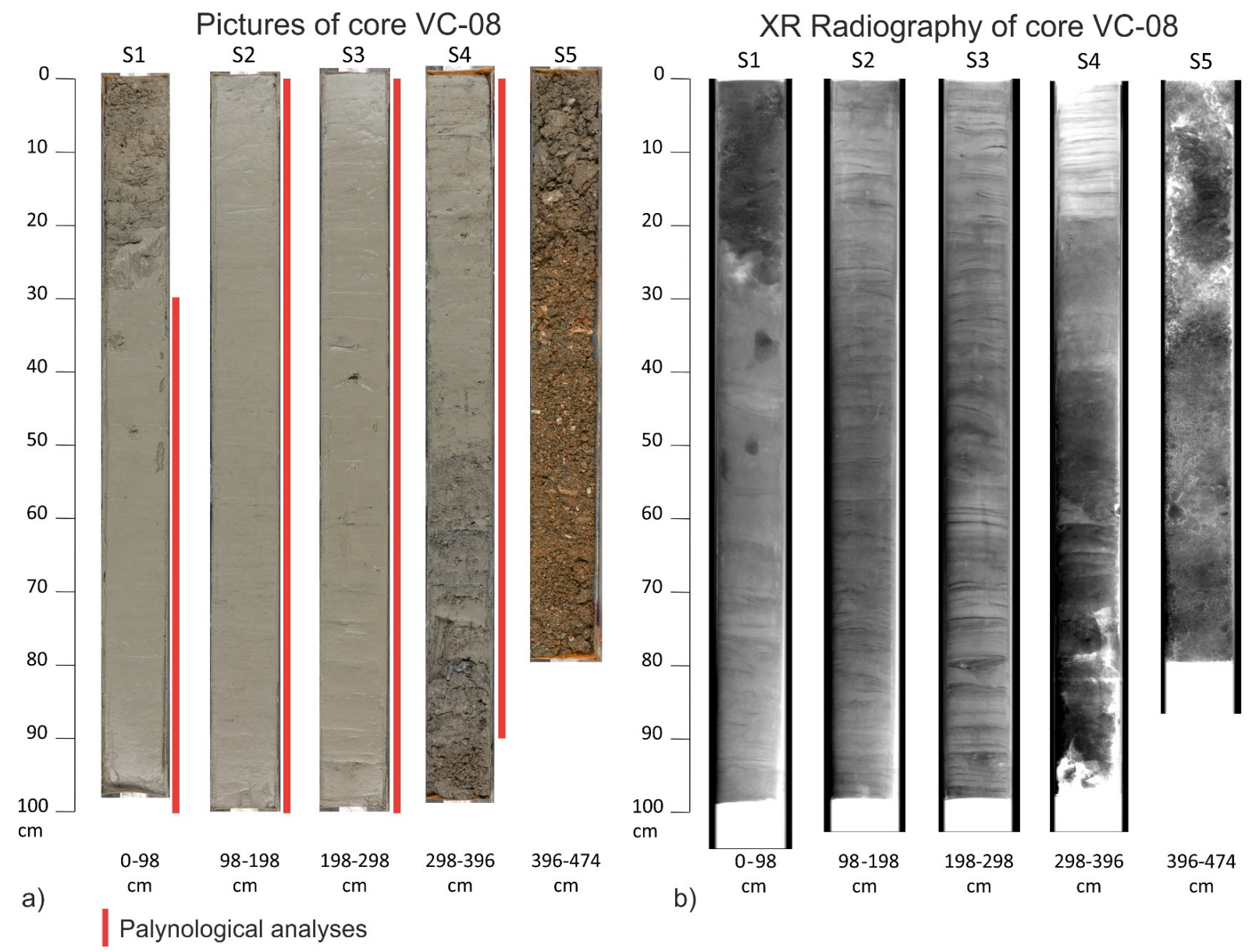

Figure 3 
a) Magnetic susceptibility, granulometry and particle size distribution


5

10

15
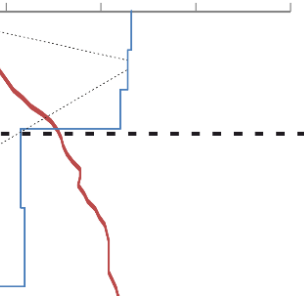

b) Core VC-08 log


$50=$


Detritic sediments

Figure 4 


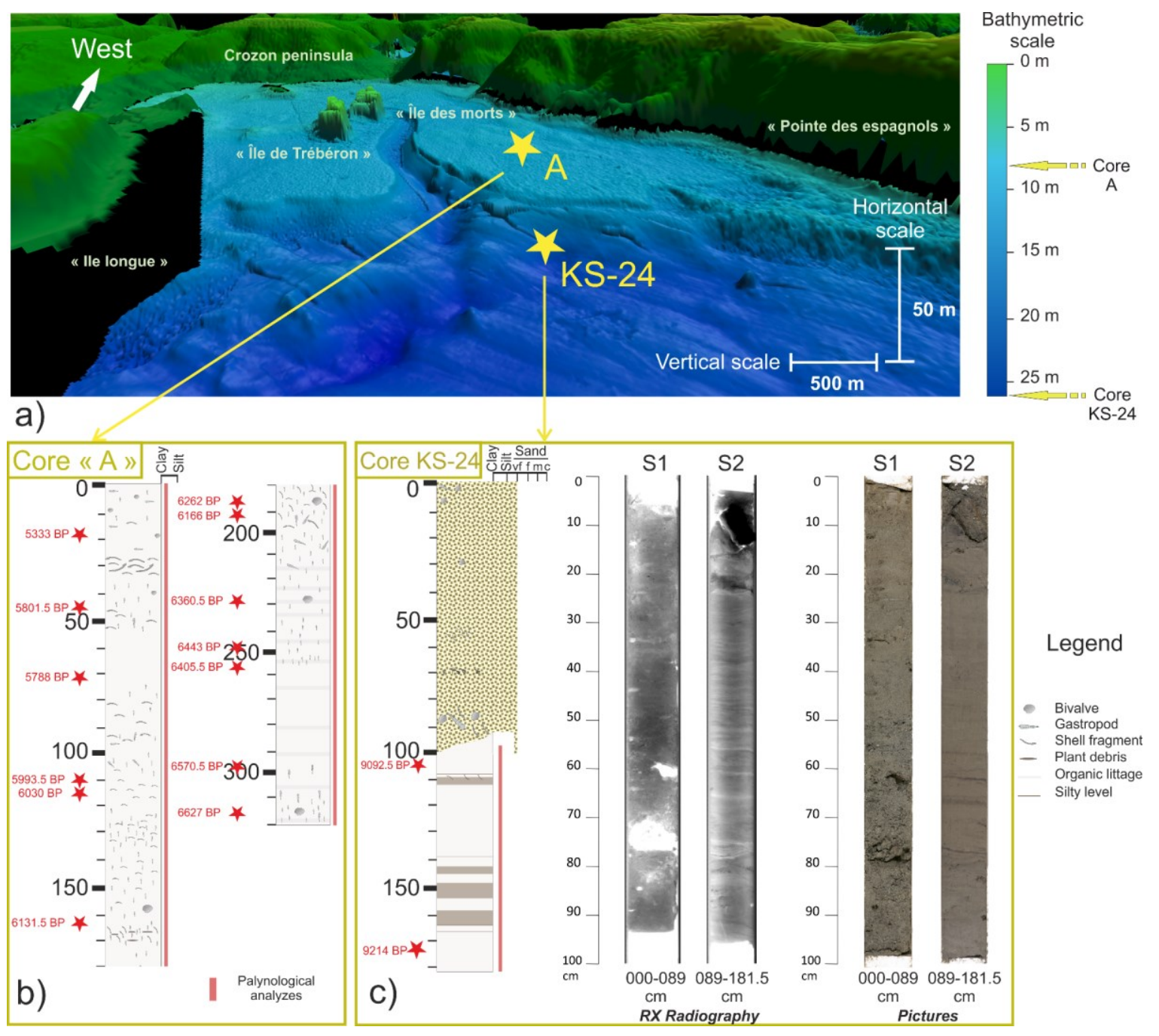

Figure 5
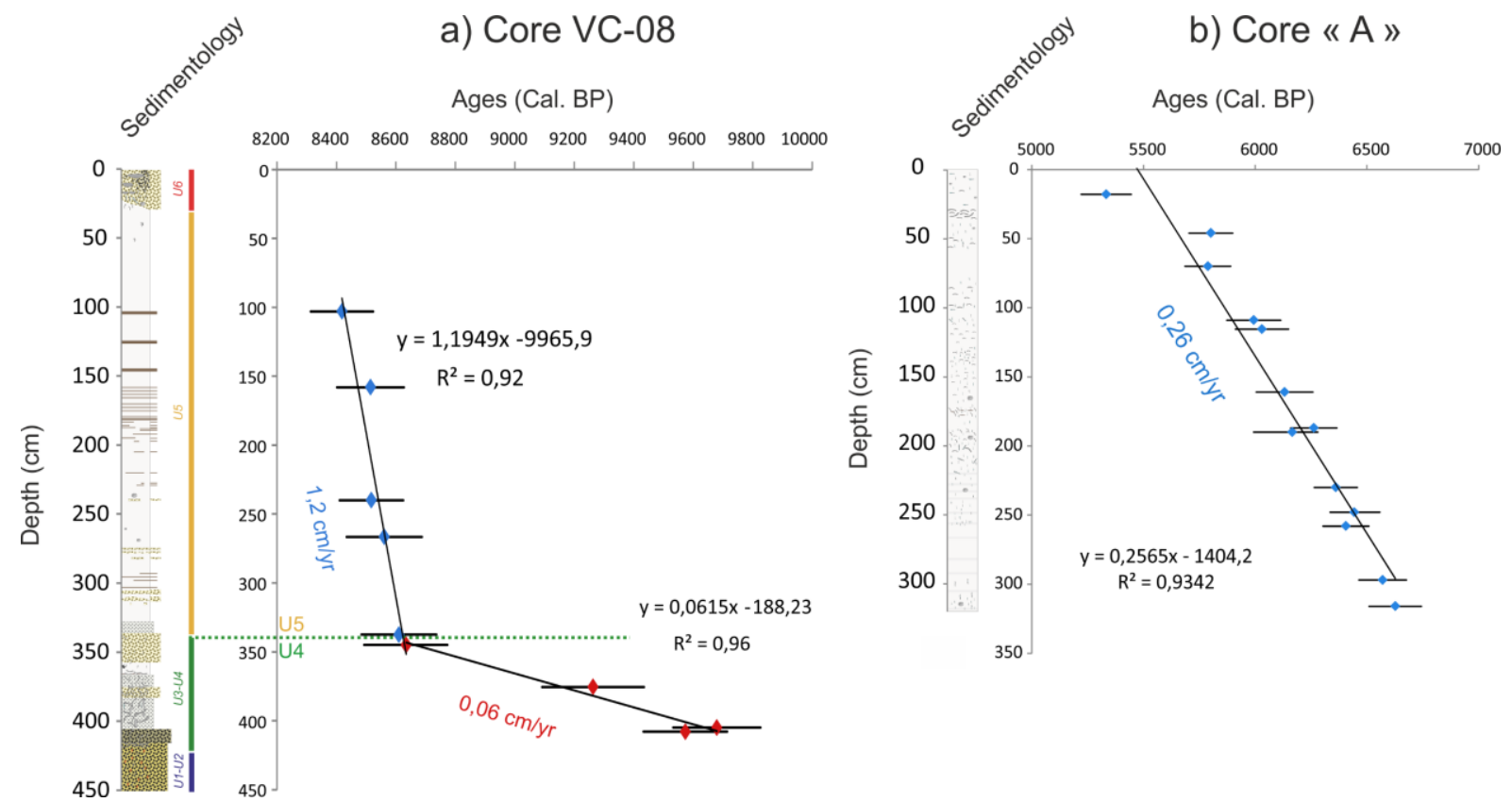

Figure 6 


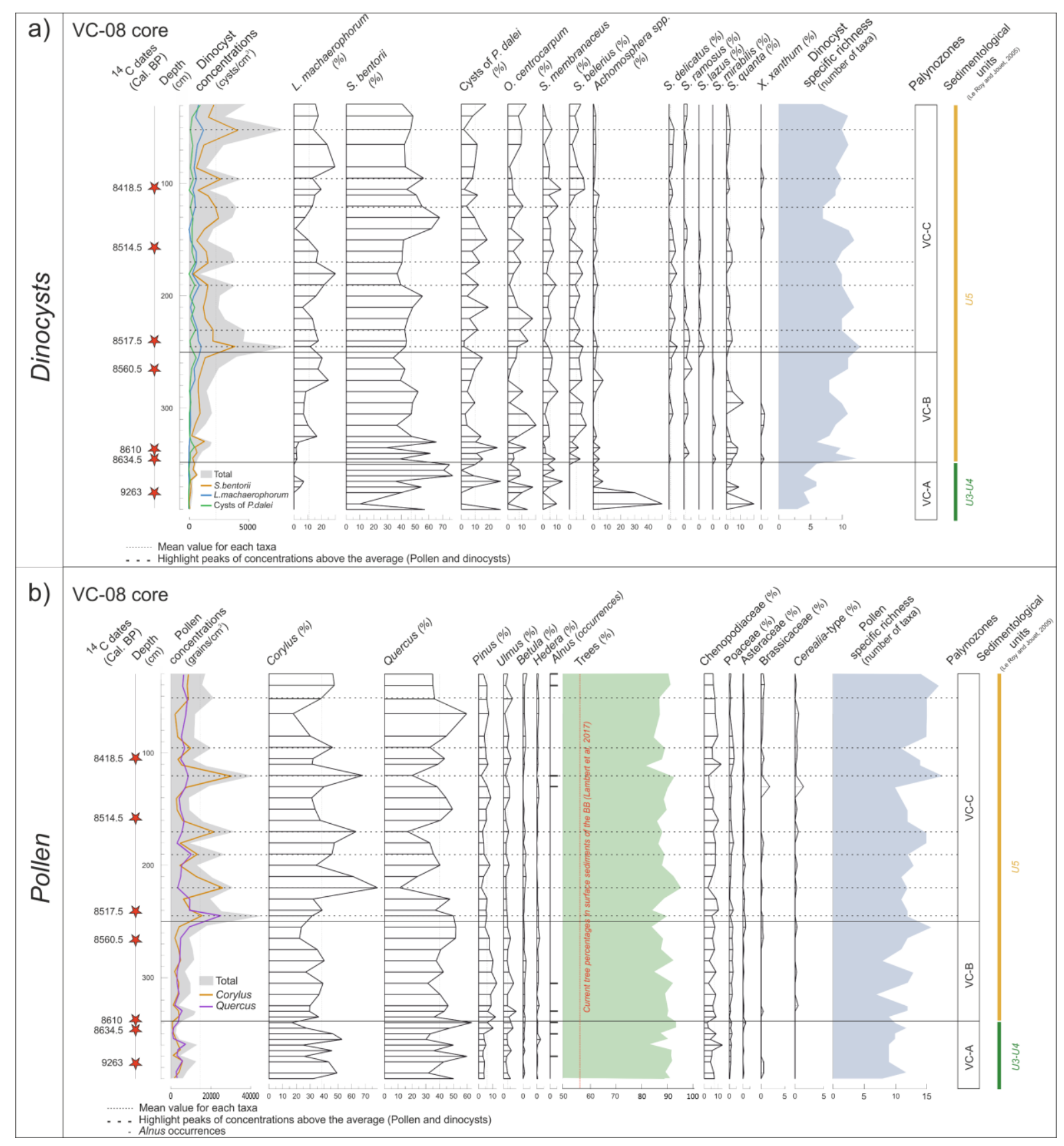

Figure 7 


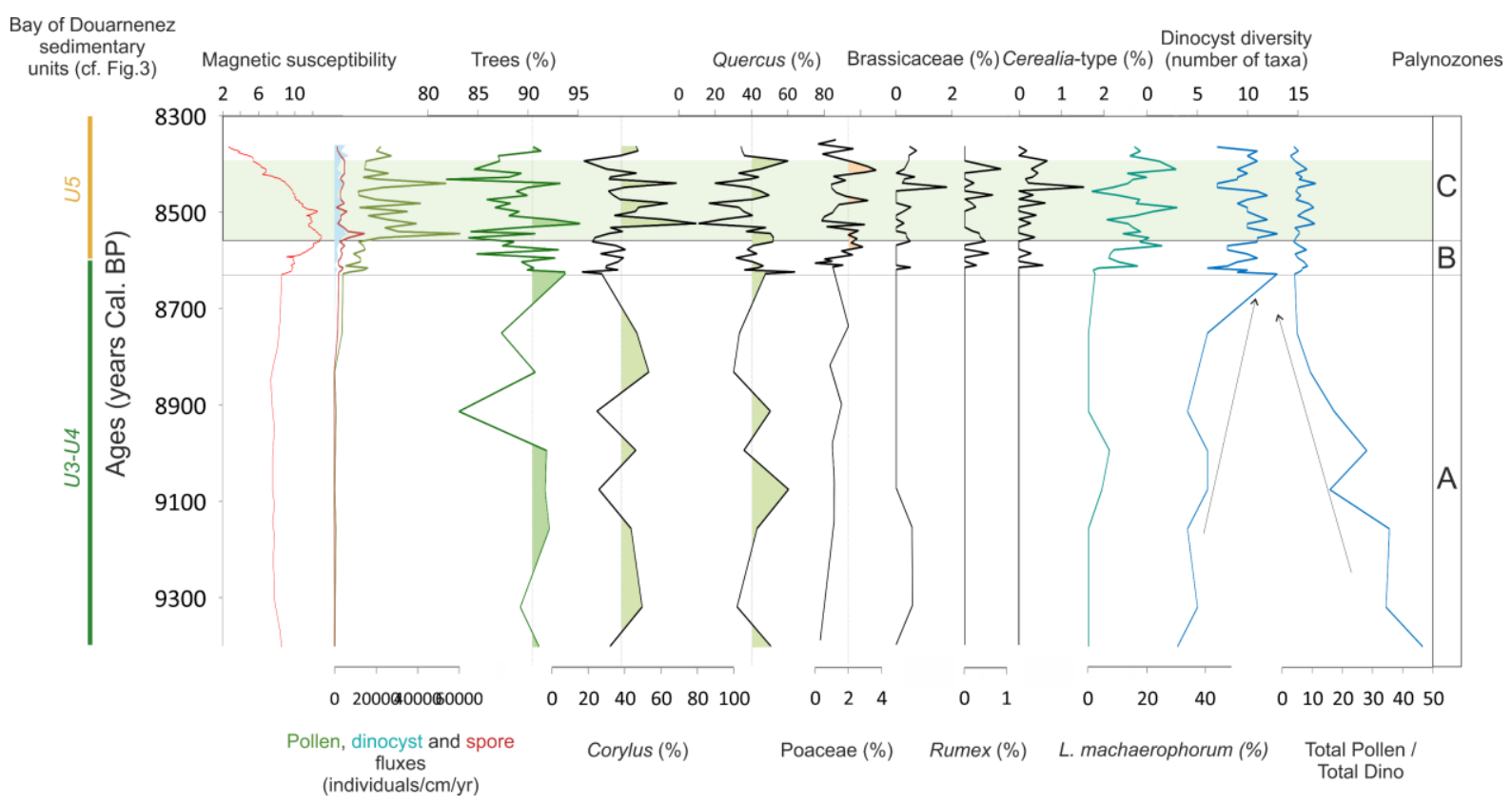

Figure 8 


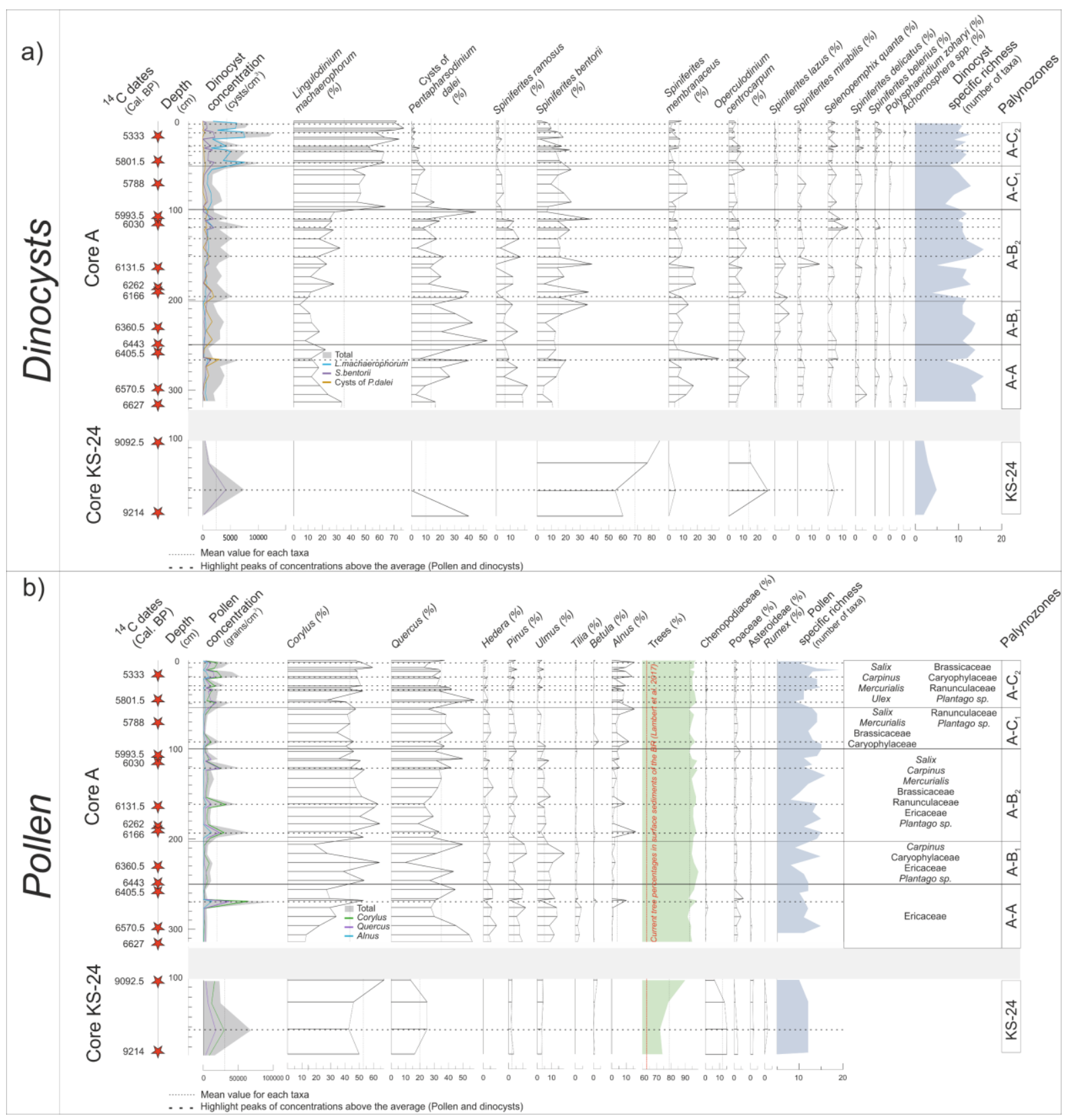

Figure 9 




Figure 10

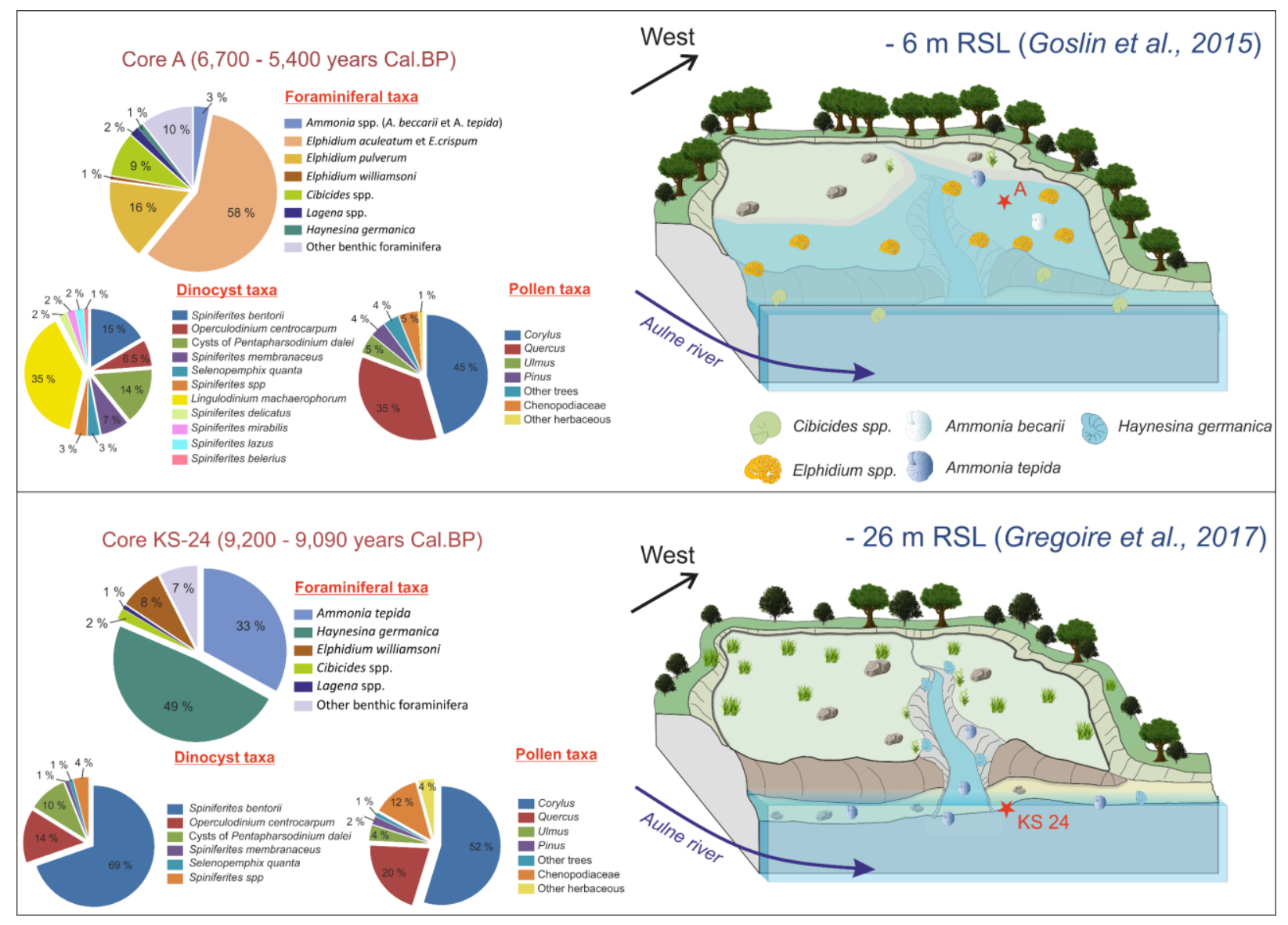

Figure 11 

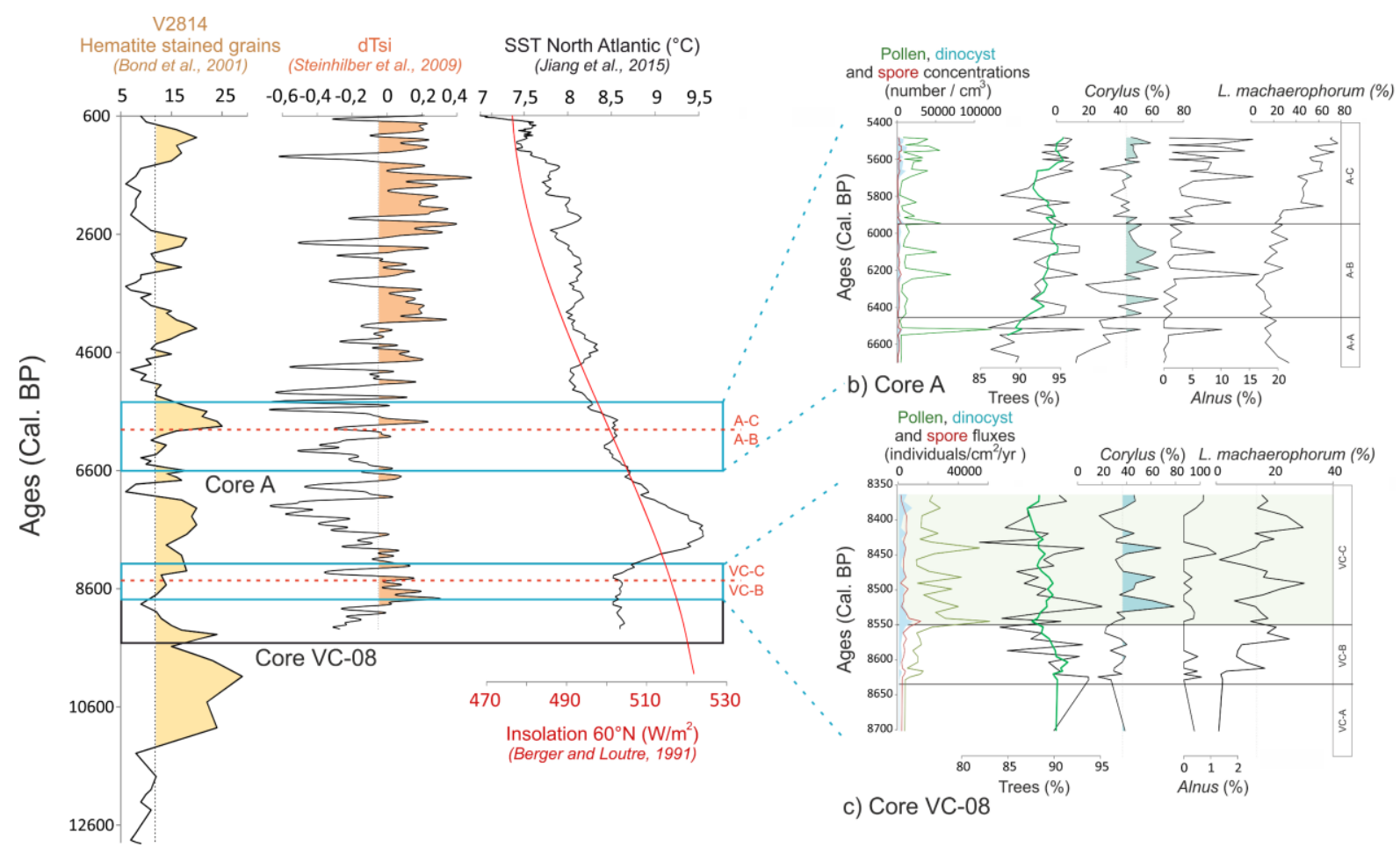

a)

Figure 12

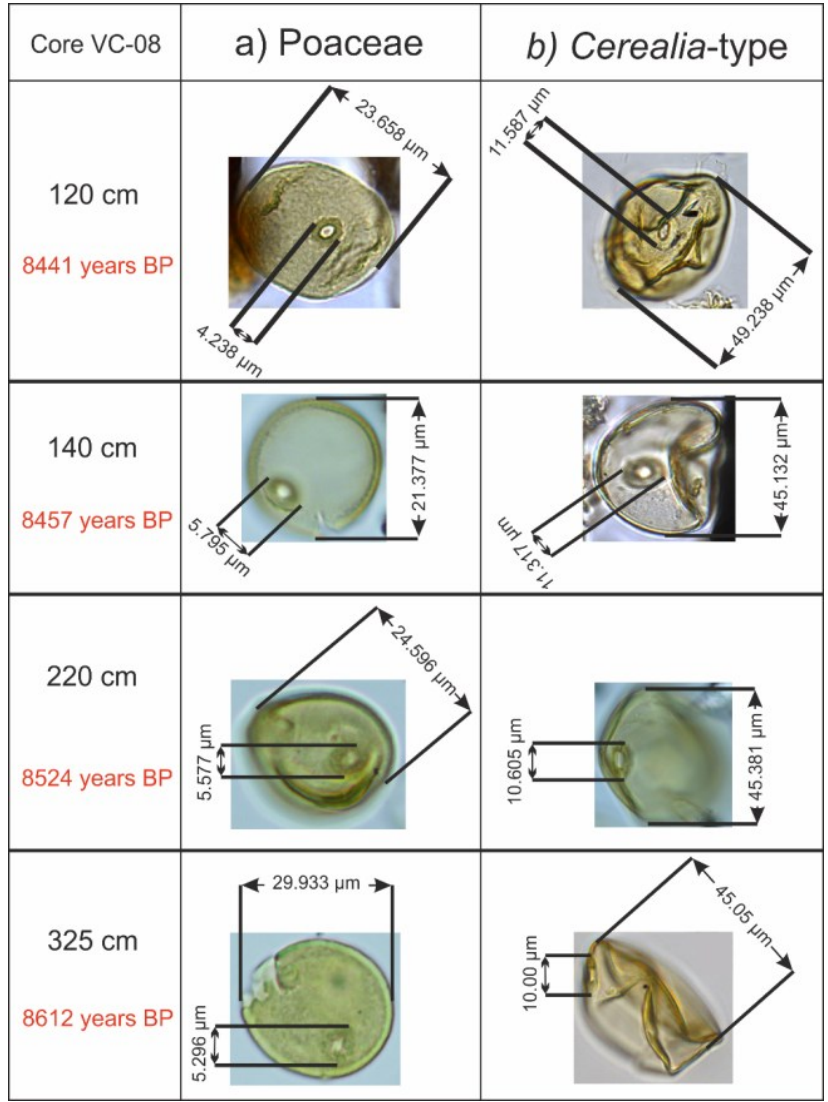

Figure 13 


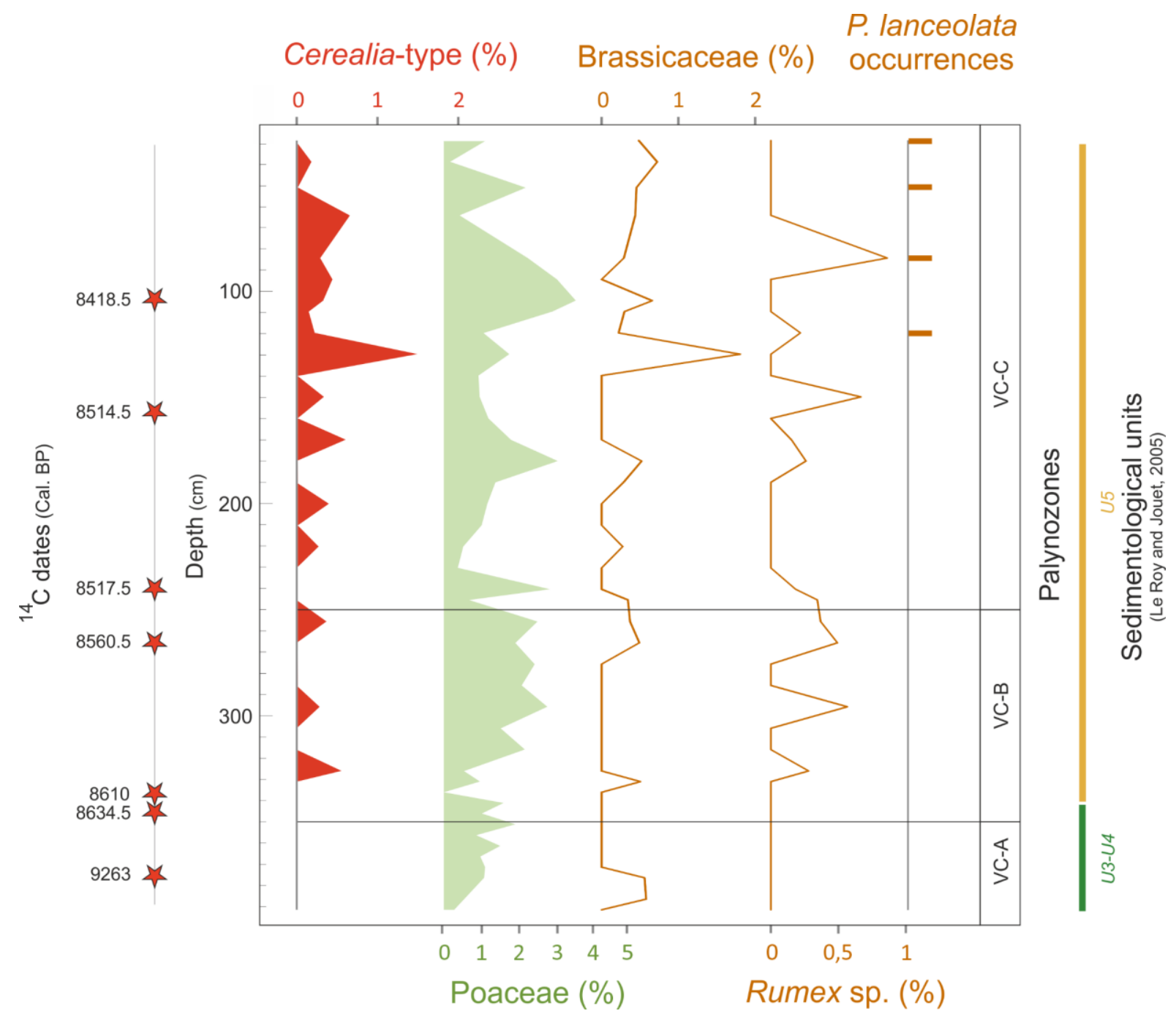

Figure 14 


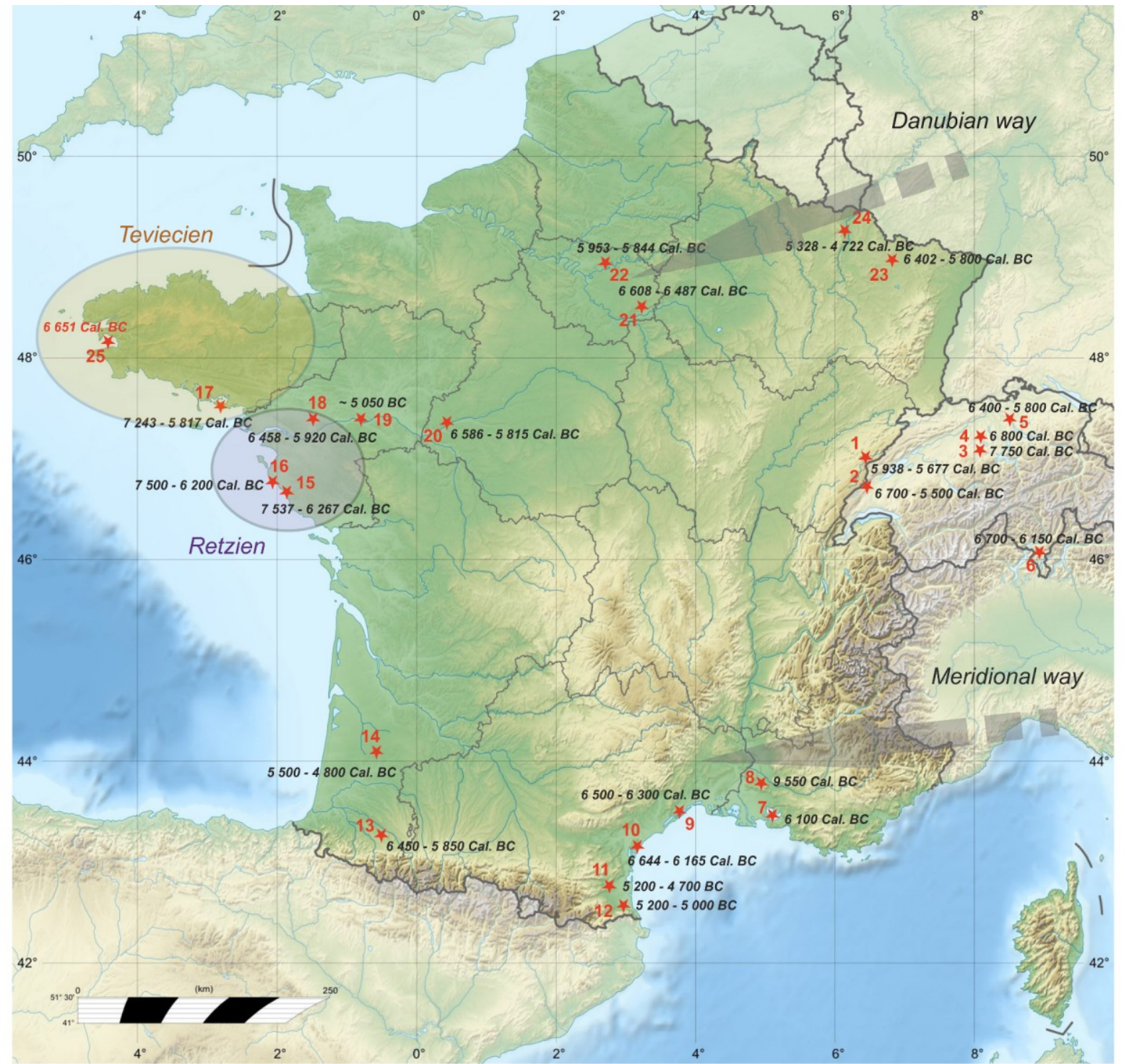

1. Cupillard et al., 1994 ; 2. Nielsen, 2003 ; 3. Lotter, 1999 and Tinner et al., 2007 ; 4. Beckmann, 2004 ;

5. Erny-Rodmann et al., 1997 ; 6. Tinner et al., 1999 ; 7, 8. Triat-Laval, 1978 ; 9. Puertas, 1999 ; 10. Guenet, 1995 ;

11. Jalut and Vernet, 1989 ; 12. Amat, 1995 ; 13. Galop and Vaquer, 2004 ; 14. Legigan and Marambat, 1993 ;

15. Joly and Visset, 2005 ; 16. Joly and Visset, 2009 ; 17. Visset et al., 1996 ; 18. Ouguerram and Visset, 2001 ;

19. Visset et al., 2001 ; 20. Carcaud et al., $2000 ; 21$, 22. Leroyer and Allenet, 2006 ; 23, 24. Ruffaldi, 1999 ;

25. This study

\section{Figure 15}

